\title{
Microstructure refinement - homogenization and flexural strength improvement of Al203 ceramics fabricated by DLP-stereolithography integrated with chemical precipitation coating process
}

Guanglin Nie ( $\nabla$ nieguanglin@gdut.edu.cn)

Guangdong University of Technology https://orcid.org/0000-0003-2887-2778

Yehua Li

Guangdong University of Technology

Pengfei Sheng

Guangdong University of Technology

Fei Zuo

Guangdong University of Technology

Haolin Wu

Guangdong University of Technology

Leiren Liu

Guangdong University of Technology

\section{Xin Deng}

Guangdong University of Technology

\section{Yiwang Bao}

China Building Materials Academy

Shanghua Wu

Guangdong University of Technology

\section{Research Article}

Keywords: Al203 ceramic, stereolithography, flexural strength, reliability, thermal conductivity, microstructure

Posted Date: October 8th, 2020

DOI: https://doi.org/10.21203/rs.3.rs-86507/v1

License: (9) This work is licensed under a Creative Commons Attribution 4.0 International License. Read Full License 
Version of Record: A version of this preprint was published at Journal of Advanced Ceramics on July 13th, 2021. See the published version at https://doi.org/10.1007/s40145-021-0473-2. 


\title{
Microstructure refinement - homogenization and flexural strength improvement of $\mathrm{Al}_{2} \mathrm{O}_{3}$ ceramics fabricated by DLP-stereolithography integrated with chemical precipitation coating process
}

\author{
Guanglin NIE ${ }^{\mathrm{a}, *}$, Yehua $\mathrm{LI}^{\mathrm{a}}$, Pengfei SHENG ${ }^{\mathrm{a}}$, Fei ZUO ${ }^{\mathrm{a}}$, Haolin WU ${ }^{\mathrm{a}}$, Leiren LIU ${ }^{\mathrm{a}}$, Xin DENG ${ }^{\mathrm{a}}$, \\ Yiwang $\mathrm{BAO}^{\mathrm{b}}$, Shanghua $\mathrm{WU}^{\mathrm{a}, *}$ \\ ${ }^{a}$ School of Electromechanical Engineering, Guangdong University of Technology, Guangzhou 510006, \\ Guangdong, PR China \\ ${ }^{b}$ State Key Laboratory of Green Building Materials, China Building Materials Academy, Beijing 100024, \\ PR China
}

\begin{abstract}
In this study, the chemical precipitation coating (CP) process was creatively integrated with DLP-stereolithography based 3D printing for refining and homogenizing the microstructure of $3 \mathrm{D}$ printed $\mathrm{Al}_{2} \mathrm{O}_{3}$ ceramic. Based on this novel approach, $\mathrm{Al}_{2} \mathrm{O}_{3}$ powder was coated with a homogeneous layer of amorphous $\mathrm{Y}_{2} \mathrm{O}_{3}$; with the coated $\mathrm{Al}_{2} \mathrm{O}_{3}$ powder found to make the microstructure of $3 \mathrm{D}$ printed $\mathrm{Al}_{2} \mathrm{O}_{3}$ ceramic more uniform and refined, as compared with the conventional mechanical mixing $(\mathrm{MM})$ of $\mathrm{Al}_{2} \mathrm{O}_{3}$ and $\mathrm{Y}_{2} \mathrm{O}_{3}$ powders. The grain size of $\mathrm{Al}_{2} \mathrm{O}_{3}$ in Sample CP is $64.44 \%$ and $51.43 \%$ lower than those in the monolithic $\mathrm{Al}_{2} \mathrm{O}_{3}$ ceramic (AL) and Sample MM, respectively. Sample CP has the highest flexural strength of 455.37 $\pm 32.17 \mathrm{MPa}$, which is $14.85 \%$ and $25.45 \%$ higher than those of Samples MM and AL, respectively; also Sample CP has the highest Weibull modulus of 16.88 among the three kinds of samples. Moreover, the fine grained Sample CP has a close thermal conductivity to the coarse grained Sample MM because of the changes in morphology of $\mathrm{Y}_{3} \mathrm{Al}_{5} \mathrm{O}_{12}$ phase from semi-connected (Sample MM) to isolated (Sample CP). Finally, specially designed fin-type $\mathrm{Al}_{2} \mathrm{O}_{3}$ ceramic heat sinks were successfully fabricated via the novel integrated process, which

Abbreviations: DLP, digital light processing; $\mathrm{MM}$, mechanical mixing; $\mathrm{CP}$, chemical precipitation coating; $\mathrm{AL}, \mathrm{Al}_{2} \mathrm{O}_{3}$.

* Corresponding author.

E-mail address: nieguanglin@gdut.edu.cn (G. Nie), swu@gdut.edu.cn (S. Wu)
\end{abstract}


has been proven to be an effective method for fabricating complex-shaped $\mathrm{Al}_{2} \mathrm{O}_{3}$ ceramic components with enhanced flexural strength and reliability.

Keywords: $\mathrm{Al}_{2} \mathrm{O}_{3}$ ceramic; stereolithography; flexural strength; reliability; thermal conductivity; microstructure

\section{Introduction}

Alumina $\left(\mathrm{Al}_{2} \mathrm{O}_{3}\right)$ ceramic has been widely used in thermal management applications, such as substrates, heat sinks and packaging materials for integrated circuits and LEDs, due to its high mechanical strength, excellent electrical insulation, high thermal conductivity as well as acceptable cost [1-3]. The power density in modern electronic systems is now increasing at an unprecedented speed, thus it is urgent to fabricate the fin-type $\mathrm{Al}_{2} \mathrm{O}_{3}$ ceramic heat sinks and microchannel substrates with complex shapes, in order to dissipate heat quickly and protect valuable electronic components effectively. However, the high hardness and low toughness of structural ceramics make it difficult to shape and machine complex-shaped ceramic parts [4]. The conventional ceramic-shaping methods, such as dry pressing, isostatic pressing, gel casting, injection molding etc. [5-7], require the use of molds, leading to increased manufacturing cost [8]; and cannot be used to fabricate $\mathrm{Al}_{2} \mathrm{O}_{3}$ ceramic parts with highly complex geometries and interconnected channels [9], thereby limiting the wide application of $\mathrm{Al}_{2} \mathrm{O}_{3}$ components. So there has been strong demand to develop a more effective approach to sidestep the aforementioned limitations and fabricate complex-shaped $\mathrm{Al}_{2} \mathrm{O}_{3}$ ceramic parts. 
Additive manufacturing, also referred to as 3D printing and rapid prototyping, is a series of advanced manufacturing technologies to construct complicated prototypes from 3D CAD models [10]. The introduction of 3D printing technologies into the fabrication of advanced ceramics can address the issues such as mold dependence and difficulties in shaping complexshaped ceramic parts [8]. Due to the excellent technical advantages of stereolithography such as high dimensional accuracy and good surface finish, efforts on applying stereolithography to ceramic fabrication have been made [11]. The stereolithography based additive manufacturing, including stereolithography apparatus (SLA) and digital light processing (DLP), is based on the controlled light-induced layer-by-layer photopolymerization of a liquid photosensitive resin mixed with ceramic powder $[8,12]$. The light engine used in the DLPstereolithography projects the mask image of sliced layers onto the surface of photosensitive ceramic suspensions, using high performance LEDs as light source and a digital micromirror device (DMD) as dynamic mask, hence it has a higher building speed compared with the SLAstereolithography and is advantageous for the fabrication of ceramic components with a very good feature resolution $[13,14]$.

To date, numerous studies have confirmed the viability and effectiveness of the stereolithography to fabricate $\mathrm{Al}_{2} \mathrm{O}_{3}$ ceramic parts. For instance, the $\mathrm{Al}_{2} \mathrm{O}_{3}$ ceramic windowpanes with fully dense microstructure were fabricated by M.L. Griffith and J.W. Halloran, who were the first to adopt stereolithography for ceramic freeform fabrication in 1996 [15]. The drying and debinding processes of SLA-stereolithography were optimized by M. Zhou et al., and a defect-free $\mathrm{Al}_{2} \mathrm{O}_{3}$ cutting tool with a relative density of $99.3 \%$ was 
obtained [16]. The DLP-stereolithography was used to prepare $\mathrm{Al}_{2} \mathrm{O}_{3}$ ceramic parts with good surface quality and a relative density of $93.2 \%$, which demonstrated the effectiveness of DLPstereolithography [11]. Works by O. Santoliquido et al. [17] and X. Shuai et al. [18] have detailed the use of DLP-stereolithography for the fabrication of $\mathrm{Al}_{2} \mathrm{O}_{3}$ architectures with fine and complex lattice structures. However, it is worth noting that the presence of photosensitive resin in printed green parts and its removal during the debinding process can result in a large porosity in the debound parts [19], which can lengthen the pathways for substance migration at high temperatures and be an obstacle for the sintering densification [20, 21]. For this reason, an increased sintering temperature is required for the debound samples to form dense ceramic parts. The exorbitant high sintering temperature $\left(1550 \sim 1750{ }^{\circ} \mathrm{C}\right)$ of stereolithography-based $3 \mathrm{D}$ printed $\mathrm{Al}_{2} \mathrm{O}_{3}$ ceramics $[15,16,22-27]$ is expected to cause the abnormal grain growth and heterogeneous microstructure of $\mathrm{Al}_{2} \mathrm{O}_{3}$ ceramics. For instance, as presented in Refs. [20] and [24], the grain sizes of the $\mathrm{Al}_{2} \mathrm{O}_{3}$ ceramics fabricated by stereolithography were 24 and 12 times larger than the average particle sizes of the feedstock $\mathrm{Al}_{2} \mathrm{O}_{3}$ powders, respectively; In addition, a satisfactory microstructure uniformity of the $\mathrm{Al}_{2} \mathrm{O}_{3}$ ceramics prepared by SLAstereolithography can hardly be obtained even if the $\mathrm{Al}_{2} \mathrm{O}_{3}$ samples were sintered at a relative low temperature $\left(1550{ }^{\circ} \mathrm{C}\right)$ [27]. The abnormal grain growth and non-uniform microstructure can result in lower flexural strength and reliability of ceramics [28, 29], which will further shorten service lifetime of ceramic substrates and heat sinks [30] and thus restrict their application in electronics. Therefore, it is urgent to refine and homogenize the microstructure of $\mathrm{Al}_{2} \mathrm{O}_{3}$ ceramics prepared by stereolithography-based 3D printing, in order to improve the 
flexural strength and reliability of $\mathrm{Al}_{2} \mathrm{O}_{3}$ ceramics.

The addition of yttria $\left(\mathrm{Y}_{2} \mathrm{O}_{3}\right)$, which strongly segregates or precipitates in the form of yttrium aluminates at $\mathrm{Al}_{2} \mathrm{O}_{3}$ grain boundaries due to its limited solubility $(<10 \mathrm{ppm})$ in $\mathrm{Al}_{2} \mathrm{O}_{3}$ crystal lattice [31, 32], is known to inhibit grain growth of $\mathrm{Al}_{2} \mathrm{O}_{3}$ and represent an effective way for microstructure refinement, through changing the activation energy of grain boundary diffusion and motion $[33,34]$. As a result, the mechanical strength of $\mathrm{Al}_{2} \mathrm{O}_{3}$ or $\mathrm{Al}_{2} \mathrm{O}_{3}$-based ceramic can be noticeably enhanced $[35,36] . \mathrm{Y}_{2} \mathrm{O}_{3}$ is conventionally doped by mechanical mixing (MM) [35], but it is difficult to obtain a homogeneous microstructure, especially a uniform distribution of yttrium aluminates by this method [37]. Compared with the conventional $\mathrm{MM}$ process, the chemical precipitation coating $(\mathrm{CP})$ process, which has been employed in the preparation of YAG, $\mathrm{SiC}$ and translucent $\mathrm{Al}_{2} \mathrm{O}_{3}$ ceramics [38-40], shows more homogeneous mixing performance and can improve the microscopic uniformity of ceramics. Furthermore, the dispersive performance of additives $\left(\mathrm{Y}_{2} \mathrm{O}_{3}\right)$ in $\mathrm{Al}_{2} \mathrm{O}_{3}$ matrix is expected to lead to the morphology change of second phases (yttrium aluminates), and the thermal conductivity of ceramics can be highly affected by the grain growth and the morphology of second phases, as commonly seen in AlN ceramic [41, 42]. Nevertheless, this CP process has never been used for the preparation of stereolithography-based $3 \mathrm{D}$ printed $\mathrm{Al}_{2} \mathrm{O}_{3}$ ceramics. To the best of our knowledge, few researches have evaluated the thermal conductivity of stereolithography-based $3 \mathrm{D}$ printed $\mathrm{Al}_{2} \mathrm{O}_{3}$ ceramics, which is significantly essential for thermal management applications of $\mathrm{Al}_{2} \mathrm{O}_{3}$ ceramics. The effect of the way of introducing additives on the thermal conductivity of $\mathrm{Al}_{2} \mathrm{O}_{3}$ ceramics has not been investigated so far. 
In this study, a CP process was used to fabricate an amorphous $\mathrm{Y}_{2} \mathrm{O}_{3}$ coating on the surface of $\mathrm{Al}_{2} \mathrm{O}_{3}$ powder, in order to improve the dispersive homogeneity of $\mathrm{Y}_{2} \mathrm{O}_{3}$ in $\mathrm{Al}_{2} \mathrm{O}_{3}$ matrix. The coating effectiveness and integrity were examined in detail by transmission electron microscopy (TEM) and X-ray photoelectron spectroscopy (XPS) measurements. In addition, to demonstrate the advantage of the $\mathrm{CP}$ process, the phase transformation, microstructure, thermal and mechanical properties comparisons were made between the $\mathrm{CP}$ and conventional $\mathrm{MM}$ processed $\mathrm{Al}_{2} \mathrm{O}_{3}$ samples. The current study shows that, as compared with the conventional $\mathrm{MM}$ process, the $\mathrm{CP}$ process is a viable approach for refining homogenizing the microstructure and enhancing the flexural strength - reliability of the DLPstereolithography based $3 \mathrm{D}$ printed $\mathrm{Y}_{2} \mathrm{O}_{3}-\mathrm{Al}_{2} \mathrm{O}_{3}$ ceramics without decreasing their thermal conductivity.

\section{Experimental procedure}

\subsection{Preparation of $\mathrm{Y}_{2} \mathrm{O}_{3}-\mathrm{Al}_{2} \mathrm{O}_{3}$ composite powders}

Commercially available $\alpha-\mathrm{Al}_{2} \mathrm{O}_{3}$ powder $\left(\mathrm{D}_{50}=200 \mathrm{~nm}\right.$, TM-DAR, Taimei Chemicals Co., Ltd., Japan) was used as starting material. $\mathrm{Y}_{2} \mathrm{O}_{3}$ additives were used to refine microstructure and enhance mechanical strength of $\mathrm{Al}_{2} \mathrm{O}_{3}$ ceramics $[33,35,37]$. Two batches of $\mathrm{Y}_{2} \mathrm{O}_{3}-\mathrm{Al}_{2} \mathrm{O}_{3}$ composite powders were prepared by the $\mathrm{CP}$ and $\mathrm{MM}$ process, respectively, and both of them

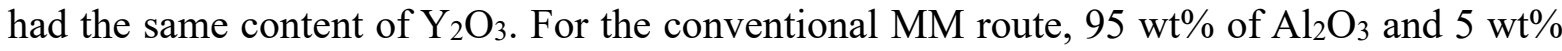
of $\mathrm{Y}_{2} \mathrm{O}_{3}\left(\mathrm{D}_{50}=500 \mathrm{~nm}\right.$, Shanghai Macklin Biochemical Co., Ltd., China) powders were ball

milled in ethanol for $6 \mathrm{~h}$ employing a planetary ball mill (QM-QX4, Nanjing NanDa 
Instrument Plant, China), with the milling speed set to $250 \mathrm{r} / \mathrm{min}$. The MM system consisted of powders / ethanol / zirconia ball at a weight ratio of 1:3:2 in a Teflon container. After ballmilling, the powders were dried in a rotary evaporator and granulated through a $150 \mu \mathrm{m}$ sieve. For the $\mathrm{CP}$ route, the non-aqueous precursor and precipitant solutions were used for avoiding hard agglomeration of $\mathrm{Y}_{2} \mathrm{O}_{3}$-coated $\mathrm{Al}_{2} \mathrm{O}_{3}$ composite powder during drying, and the whole $\mathrm{CP}$ process is shown in Fig. 1. Firstly, $\mathrm{Y}\left(\mathrm{NO}_{3}\right)_{3} \cdot 6 \mathrm{H}_{2} \mathrm{O}(99.99 \%$ purity, Shanghai Aladdin BioChem Technology Co., Ltd., China) was dissolved in ethanol to prepare the precursor solution, where the concentration of $\mathrm{Y}^{3+}$ was accurately controlled to $0.05 \mathrm{~mol} / \mathrm{L}$. Secondly, the $\mathrm{Al}_{2} \mathrm{O}_{3}$ powder was slowly added in the prepared precursor solution, and mixed with $1.5 \mathrm{wt} \%$ of dispersants of polyethylene glycol (PEG 2000). The weight ratio of the $\mathrm{Y}_{2} \mathrm{O}_{3}$ (calculated based on the transformation of $\mathrm{Y}\left(\mathrm{NO}_{3}\right)_{3}$ to $\left.\mathrm{Y}_{2} \mathrm{O}_{3}\right)$ to $\mathrm{Al}_{2} \mathrm{O}_{3}$ was set to 5:95. Thirdly, the above suspension was dispersed in a bath under ultrasound for $60 \mathrm{~min}$, and then vigorously stirred for 120 min to prevent the sedimentation of ceramic particles. Fourthly, the mixed solution $(\mathrm{pH}=12.66)$ of ethylenediamine (EDA) and ethanol with the weight ratio of $1: 2$ was prepared as the precipitant solution, and was slowly dropped into the ceramic suspension under strong mechanical stirring to tailor the $\mathrm{pH}$ value of the suspension in the range of 9.3 9.5. During the dripping process of the precipitant solution, the precipitations of yttrium-amine complex were formed and simultaneously deposited on the $\mathrm{Al}_{2} \mathrm{O}_{3}$ powder surface, which can act as the preferential heterogeneous nucleation sites [43]. After the above precipitation coating process, the resultant suspension was continuously stirred for $120 \mathrm{~min}$. Then, the as-prepared composite ceramic powder $\left(\mathrm{Al}_{2} \mathrm{O}_{3}\right.$ coated with the yttrium-amine complexes) were washed 
with ethanol and air-dried at $60^{\circ} \mathrm{C}$ for $10 \mathrm{~h}$. Finally, the dried products were calcined at $450{ }^{\circ} \mathrm{C}$ for $2 \mathrm{~h}$ to decompose yttrium-amine complexes into $\mathrm{Y}_{2} \mathrm{O}_{3}$, and the calcined powder was granulated through a $150 \mu \mathrm{m}$ sieve.
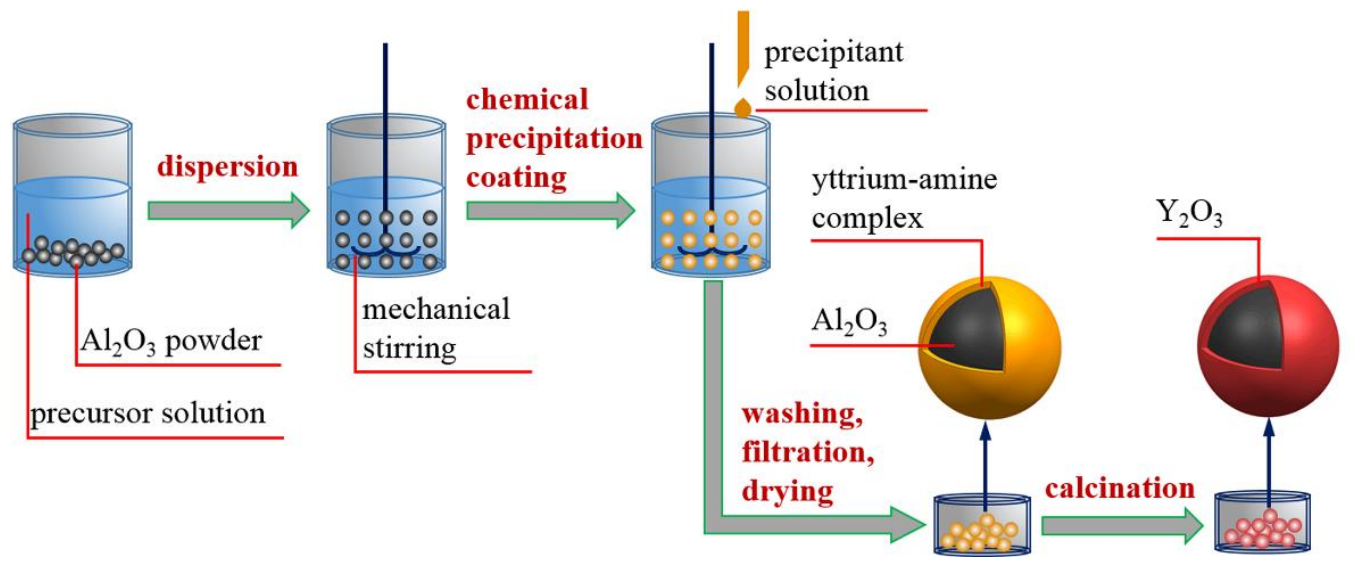

Fig. 1 Schematic illustration of the chemical precipitation coating process.

\subsection{Preparation of UV-curable ceramic suspension}

Before the preparation of UV-curable ceramic suspensions, the pure $\mathrm{Al}_{2} \mathrm{O}_{3}, \mathrm{MM}$ and $\mathrm{CP}$ processed $\mathrm{Y}_{2} \mathrm{O}_{3}-\mathrm{Al}_{2} \mathrm{O}_{3}$ powders were separately surface modified with oleic acid $(\mathrm{OA}$, Shanghai Aladdin Bio-Chem Technology Co., Ltd., China). Firstly, the ceramic powder was dispersed in ethanol, and $1.0 \mathrm{wt} \%$ of OA with respect to the mass of ceramic powder was used as surface modifier. The suspension was ball-milled for $2 \mathrm{~h}$ employing a planetary ball mill to facilitate physical adsorption of OA on powder surface. Then the suspension was dried at $50{ }^{\circ} \mathrm{C}$ for $12 \mathrm{~h}$ to remove ethanol and the remaining powder was thermally treated at $80{ }^{\circ} \mathrm{C}$ for $6 \mathrm{~h}$ to promote chemical adsorption [27, 44]. Finally, the treated ceramic powder was deagglomerated by passing them through a $150 \mu \mathrm{m}$ sieve.

The UV-curable ceramic suspension was prepared by adding $79 \mathrm{wt} \%$ of above modified 
ceramic powder into the photosensitive resin, which was fabricated by mixing ethoxylated pentaerythritol tetraacrylate (PPTTA, Royal DSM, Netherlands), 1,6-hexanediol diacrylate (HDDA, Royal DSM, Netherlands), di-functional aliphatic polyurethane acrylate (U600, Royal DSM, Netherlands), octanol (Shanghai Aladdin Bio-Chem Technology Co., Ltd., China), polyethylene glycol (Shanghai Aladdin Bio-Chem Technology Co., Ltd., China) with commercial dispersant (BYK9077, BYK Additives \& Instruments, Germany). The above ceramic suspension was ball-milled for $6 \mathrm{~h}$ at $350 \mathrm{r} / \mathrm{min}$ using a planetary ball mill. After the ball-milling process, the photoinitiator (Irgacure819, BASF, Germany), with an effective absorption peak range well matched with the wavelength of the UV light used for DLP processing in this study, was mixed into the homogeneous suspension to produce a UV-curable ceramic suspension.

\subsection{DLP-stereolithography based 3D printing}

3D printing was performed at room temperature by using a DLP-stereolithograpgy based apparatus. The UV light source of the DLP printer is below the vat and has a wavelength of $405 \mathrm{~nm}$ with a light intensity of $10.5 \mathrm{~mW} / \mathrm{cm}^{2}$. A 3D model was first created using the UG software and output to a STL file, then the STL file was imported into the stereolithography machine and sliced into $2 \mathrm{D}$ images. The $\mathrm{Al}_{2} \mathrm{O}_{3}$ green bodies were obtained by DLPstereolithography using the above-mentioned ceramic suspensions. During the DLPstereolithography process, the UV light selectively cured the photosensitive resin in ceramic suspension based on the $2 \mathrm{D}$ images and created cross-linked polymer networks to bond 
ceramic particles together. The photopolymerisation process was generally proceeded in a layer-by-layer pattern. The layer thickness was set to $20 \mu \mathrm{m}$, and the cure depth was $83.00 \pm 2.51 \mu \mathrm{m}$ by adjusting the exposure time to $3.0 \mathrm{~s}$, giving a high vertical resolution and an adequate integration between layers. Once a single layer was cured, the vat was tilted down to detach the cured layer and the building platform was lifted to allow recoating the suspension layer at the bottom of the vat. Then the new layer was cured subsequently in exactly the same fashion. These steps were repeated until the whole green body was eventually fabricated.

\subsection{Debinding and sintering}

For printed $\mathrm{Al}_{2} \mathrm{O}_{3}$ green bodies, the post-processing steps including debinding and sintering were carried out to obtain $\mathrm{Al}_{2} \mathrm{O}_{3}$ ceramic parts. A two-step debinding process was adopted in this work [16], in which green bodies were firstly debound under vacuum to decelerate pyrolysis rate of resins and then debond in air to completely remove the residual carbon. The debound samples were subsequently sintered in a muffle furnace (HTK 16/18, Thermconcept, Germany) at $10^{\circ} \mathrm{C} / \mathrm{min}$ from room temperature to $800^{\circ} \mathrm{C}$, then at $5{ }^{\circ} \mathrm{C} / \mathrm{min}$ up to $1650{ }^{\circ} \mathrm{C}$, with a final plateau of $2 \mathrm{~h}$. Finally the furnace was cooled at $5{ }^{\circ} \mathrm{C} / \mathrm{min}$ to $800{ }^{\circ} \mathrm{C}$, and then naturally cooled to room temperature. The sintered specimens were machined and polished to evaluate their thermal and mechanical properties. The $3 \mathrm{D}$ printed $\mathrm{Al}_{2} \mathrm{O}_{3}$ ceramics fabricated using the $\mathrm{MM}$ and $\mathrm{CP}$ processed (i.e., ball-milled and coated) $\mathrm{Y}_{2} \mathrm{O}_{3}-\mathrm{Al}_{2} \mathrm{O}_{3}$ composite powders are referred to as Sample MM and Sample CP, respectively. In addition, the monolithic $\mathrm{Al}_{2} \mathrm{O}_{3}$ reference samples prepared by pure $\mathrm{Al}_{2} \mathrm{O}_{3}$ powder are referred to as 
Sample AL.

\subsection{Characterization}

The microstructure and element analysis of the coated $\mathrm{Al}_{2} \mathrm{O}_{3}$ powder were investigated by a transmission electron microscopy (TEM, Talos F200S, Thermo Fisher Scientific Inc., America) coupled with an energy dispersive spectroscope (EDS). The TEM sample (coated $\mathrm{Al}_{2} \mathrm{O}_{3}$ powder) was dispersed in ethanol with ultrasonic treatment and then dropped onto a holey-carbon-coated copper grid. An X-ray photoelectron spectroscopy (XPS, Escalab 250Xi, Thermo Fisher Scientific Inc., America) was used to study the surface chemistry of the MM and $\mathrm{CP}$ processed $\mathrm{Y}_{2} \mathrm{O}_{3}-\mathrm{Al}_{2} \mathrm{O}_{3}$ powders. The contents of $\mathrm{Y}$ and $\mathrm{Al}$ in the $\mathrm{MM}$ and $\mathrm{CP}$ processed $\mathrm{Y}_{2} \mathrm{O}_{3}-\mathrm{Al}_{2} \mathrm{O}_{3}$ powders were determined by an X-ray fluorescence spectrometer (XRF-1800, Shimadzu Co., Ltd., Japan), in order to identify whether both composite powders have the same chemical compositions.

The relative density of the sintered $\mathrm{Al}_{2} \mathrm{O}_{3}$ ceramic samples was measured by Archimedes method using an analytical balance with an accuracy of $0.0001 \mathrm{~g}$. The bending strength of samples with a size of $1.5 \mathrm{~mm} \times 2.0 \mathrm{~mm} \times 25 \mathrm{~mm}$ was evaluated by three-point bending tests [45]. The loading experiments were performed using a universal mechanical testing machine (Inspekt Table Blue 05, Hegewald \& Peschke, Germany), with the crosshead speed set to 0.5 $\mathrm{mm} / \mathrm{min}$ and the supporting span of $20 \mathrm{~mm}$. A laser thermal conductivity instrument (LFA 447, Netzsch Instruments Co., Ltd., Germany) was used to determine the thermal diffusivity $(\alpha)$ of the sintered $\mathrm{Al}_{2} \mathrm{O}_{3}$ samples with a size of $10 \mathrm{~mm} \times 10 \mathrm{~mm} \times 2 \mathrm{~mm}$ at room temperature. The 
value of the thermal conductivity $(\lambda)$ for samples was calculated from:

$$
\lambda=\alpha \cdot \rho \cdot C
$$

where $\alpha$ is the thermal diffusivity, $\rho$ is the density and $C$ is the specific heat capacity of the prepared samples [46]. In the present work, the thermal conductivity of Sample AL was determined by taking the specific heat capacity value of the high purity $\mathrm{Al}_{2} \mathrm{O}_{3}$ ceramics $(0.755$ $\mathrm{J} \cdot \mathrm{g}^{-1} \cdot \mathrm{K}^{-1}$ at room temperature) [47]. $\mathrm{Y}_{2} \mathrm{O}_{3}$ doping can result in the formation of a second phase (yttrium aluminum garnet, $\mathrm{YAG}$ ) in $\mathrm{Al}_{2} \mathrm{O}_{3}$ ceramic [37], and the specific heat capacities of the $\mathrm{Y}_{2} \mathrm{O}_{3}-\mathrm{Al}_{2} \mathrm{O}_{3}$ system (Samples MM and $\mathrm{CP}$ ) were calculated by using the Neumann-Kopp rule [48]:

$$
C=\sum_{i=1}^{n} \omega_{i} C_{i}
$$

where $\omega_{i}$ is the mass fraction of each phase which can be determined by XRD analysis, and $C_{i}$ is the corresponding specific heat capacity for the constituents $\left(\mathrm{Al}_{2} \mathrm{O}_{3}\right.$ and $\left.\mathrm{YAG}\right) . \mathrm{A}$ documented value of $0.60 \mathrm{~J} \cdot \mathrm{g}^{-1} \cdot \mathrm{K}^{-1}$ is used for the specific heat capacity of YAG $[49,50]$.

The phase composition of the sintered samples was determined by X-ray diffraction (XRD, D8 Advance, Bruker Corporation, Germany). A scanning range of $2 \theta$ from $10^{\circ}$ to $80^{\circ}$ was applied. The mass percentage of the phases in the sintered sample was also semiquantitatively estimated by analyzing the reference intensity ratio (RIR) value taken from the X-ray pattern [51]. The weight fraction of phase 1 in the sintered ceramics can be calculated from:

$$
X_{1}=\frac{I_{1}}{R I R_{1}} \cdot \frac{1}{\sum_{i=1}^{n}\left(I_{i} / R I R_{i}\right)}
$$


where $X_{1}$ is the weight fraction of phase $1, I_{i}$ is the integrated intensity of the highest peak of the $i$ th phase in the analyzed ceramic, $R I R_{i}$ is the reference intensity ratio of the $i$ th phase (taken from the powder diffraction database), and $n$ is the number of phases in the prepared ceramics.

To identify the fracture surface features and global distribution profile of Y element throughout the 3D printed samples, the images of fracture surface and the corresponding $\mathrm{X}$ ray mapping analysis of $\mathrm{Y}$ element were studied by a scanning electron microscopy (SEM, LYRA 3 XMU, Tescan, Czech) coupled with an energy-dispersive spectroscopy (EDS, Inca X-Max50, Oxford Instruments, England). Moreover, the prepared samples were polished with diamond paste and then thermally etched at $1550{ }^{\circ} \mathrm{C}$ for $30 \mathrm{~min}$. The microstructures of the polished and fracture surface of the sintered ceramics were characterized by the scanning electron microscopy. The average grain size was determined by the Nanomeasure software, and at least 600 grain sizes were statistically analyzed for each sample. The Christiansen uniformity coefficient $(C U)$ was used to quantitatively determine the distribution uniformity of the grain size in the sintered ceramics, which can be calculated using the following equations [52]:

$$
\begin{aligned}
& C U=1-\sum_{i=1}^{n} \frac{\left|x_{i}-\bar{x}\right|}{n \bar{x}} \\
& \text { where } \bar{x} \text { is the average grain size, which can be calculated by } \bar{x}=\frac{1}{n} \sum_{i=1}^{n} x_{i}, x_{i} \text { is the size of the }
\end{aligned}
$$

$i$ th grain, $n$ is the total number of grains, $C U$ is the Christiansen uniformity coefficient, and the larger $C U$ value indicates the more uniform microstructure of sintered ceramic. 


\section{Results and Discussion}

\subsection{Characterization of $\mathrm{CP}$ processed $\mathrm{Al}_{2} \mathrm{O}_{3}$ powder}

The weight percent of $\mathrm{Y} /(\mathrm{Y}+\mathrm{Al})$ of the $\mathrm{MM}$ and $\mathrm{CP}$ processed $\mathrm{Y}_{2} \mathrm{O}_{3}-\mathrm{Al}_{2} \mathrm{O}_{3}$ composite powders were measured to be $7.12 \mathrm{wt} \%$ and $7.40 \mathrm{wt} \%$, respectively, by an XRF spectrometer, indicating that the composite powders prepared by MM and $\mathrm{CP}$ processes have nearly the same $\mathrm{Y}_{2} \mathrm{O}_{3}$ content. The microstructure of the $\mathrm{CP}$ processed composite powder was analyzed. TEM results of the $\mathrm{CP}$ processed $\mathrm{Y}_{2} \mathrm{O}_{3}-\mathrm{Al}_{2} \mathrm{O}_{3}$ powder are presented in Fig. 2. The morphology of the $\mathrm{CP}$ processed $\mathrm{Y}_{2} \mathrm{O}_{3}-\mathrm{Al}_{2} \mathrm{O}_{3}$ powder is shown in Fig. 2a, which displays that an evident shell layer was closely, uniformly attached to the $\mathrm{Al}_{2} \mathrm{O}_{3}$ particle surface. From a high resolution image as shown in Fig. $2 \mathrm{~b}$, the $\mathrm{CP}$ processed $\mathrm{Y}_{2} \mathrm{O}_{3}-\mathrm{Al}_{2} \mathrm{O}_{3}$ powder has a typical core-shell structure with a relatively smooth surface layer, which is about $\sim 2.31 \mathrm{~nm}$ thick. According to a further fast Fourier transform (FFT) pattern analysis, the dispersive diffraction halo in Fig. $2 \mathrm{c}$ shows that the shell is amorphous; and Fig. $2 \mathrm{~d}$ presents the lattice fringes of $\mathrm{Al}_{2} \mathrm{O}_{3}(2-13)$ and (-114) planes with interplanar spacing of about $0.201 \mathrm{~nm}$ and $0.259 \mathrm{~nm}$, respectively, indicating that the core is $\mathrm{Al}_{2} \mathrm{O}_{3}$ crystalline. This result verifies that a uniform amorphous deposition was formed on the surface of the $\mathrm{Al}_{2} \mathrm{O}_{3}$ particle. To check the element compositions of the amorphous layer, the EDS analyses were conducted on both amorphous layer (shell) and the bulk of the $\mathrm{Al}_{2} \mathrm{O}_{3}$ particle (core), shown in Fig. 2e and $2 \mathrm{f}$, respectively. The major elements in shell are $\mathrm{Al}, \mathrm{Y}, \mathrm{O}$ with minor $\mathrm{C}$ and $\mathrm{Cu}$, meanwhile, only $\mathrm{Al}, \mathrm{O}, \mathrm{C}$ and $\mathrm{Cu}$ peaks can be detected in the core. The $\mathrm{C}$ and $\mathrm{Cu}$ elements come from the holey-carbon-coated copper grid used in the TEM sample preparation. This EDS result indicates that the chemical 
composition of the shell is Y-O compound. The TEM and EDS results suggest that the $\mathrm{Al}_{2} \mathrm{O}_{3}$ particle is encapsulated by the amorphous layer of $\mathrm{Y}-\mathrm{O}$ compound.
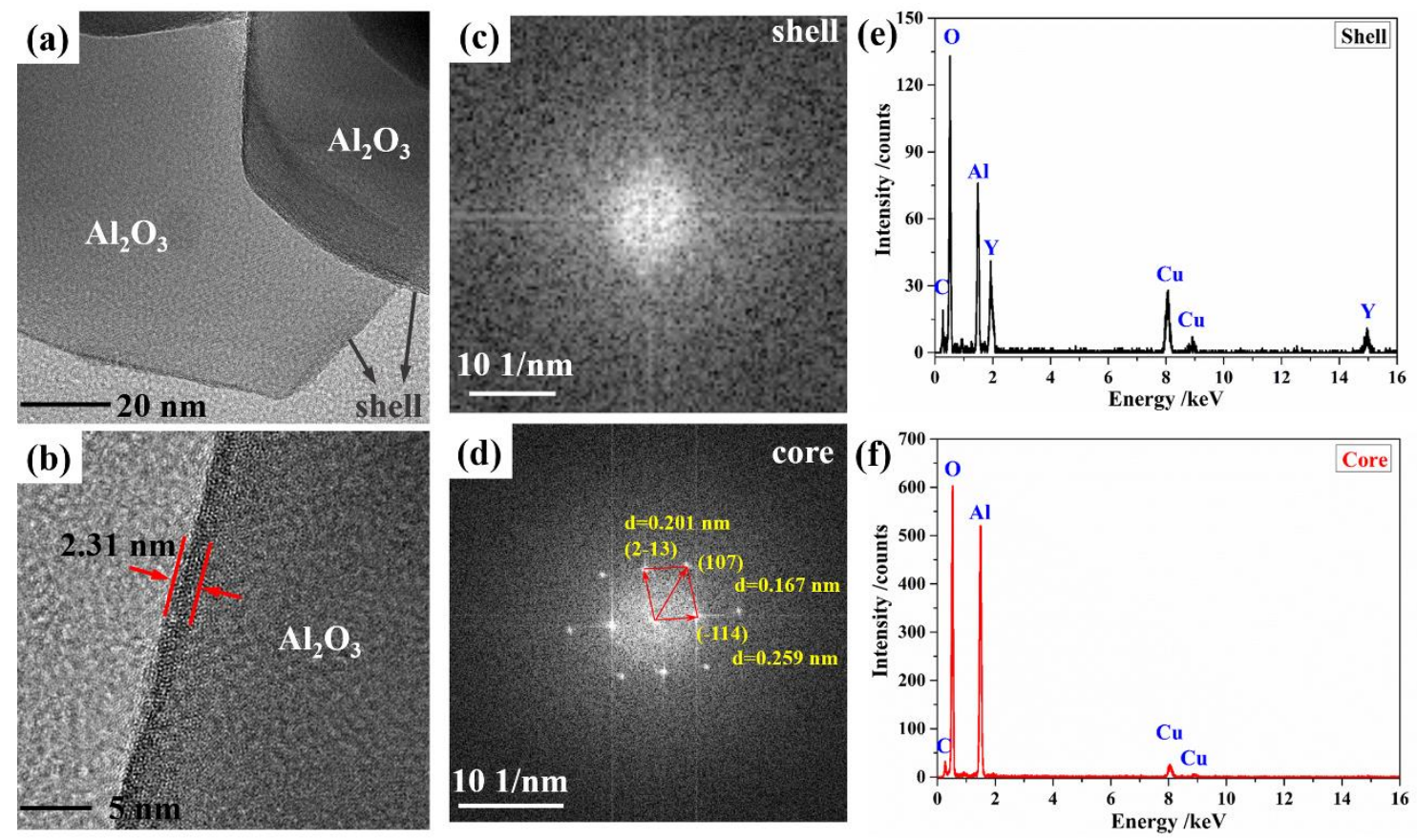

Fig. 2 (a) Representative TEM image of the $\mathrm{CP}$ processed $\mathrm{Y}_{2} \mathrm{O}_{3}-\mathrm{Al}_{2} \mathrm{O}_{3}$ ceramic powder,

(b) high magnification TEM image representing the surface of the CP processed powder, (c)

and (d) are the corresponding fast Fourier transform patterns of the shell and core, (e) and (f) are respective EDS spectra recorded from the shell and core.

The XRD patterns for the $\mathrm{MM}$ and $\mathrm{CP}$ processed $\mathrm{Y}_{2} \mathrm{O}_{3}-\mathrm{Al}_{2} \mathrm{O}_{3}$ composite powders are shown in Fig. 3. The diffraction peaks of the MM processed composite powder can be identified as phases of $\alpha-\mathrm{Al}_{2} \mathrm{O}_{3}$ and cubic $\mathrm{Y}_{2} \mathrm{O}_{3}$, indicating that the MM processed powder is a mixture of $\alpha-\mathrm{Al}_{2} \mathrm{O}_{3}$ and $\mathrm{Y}_{2} \mathrm{O}_{3}$ powders. However, the XRD pattern of the CP processed composite powder only shows sharp diffraction peaks assigned to $\alpha-\mathrm{Al}_{2} \mathrm{O}_{3}$, and a very broad peak of $\mathrm{Y}_{2} \mathrm{O}_{3}$ is present at $29.15^{\circ}$ (which is the diffraction angle of the strongest diffraction peak of $\mathrm{Y}_{2} \mathrm{O}_{3}$ ), implying that the $\mathrm{Y}_{2} \mathrm{O}_{3}$ in the $\mathrm{CP}$ processed composite powder is amorphous. 
This result is consistent with the TEM observation and corresponding FFT pattern of the amorphous shell of the coated $\mathrm{Al}_{2} \mathrm{O}_{3}$ powder (Figs. $2 \mathrm{~b}$ and $2 \mathrm{c}$ ).
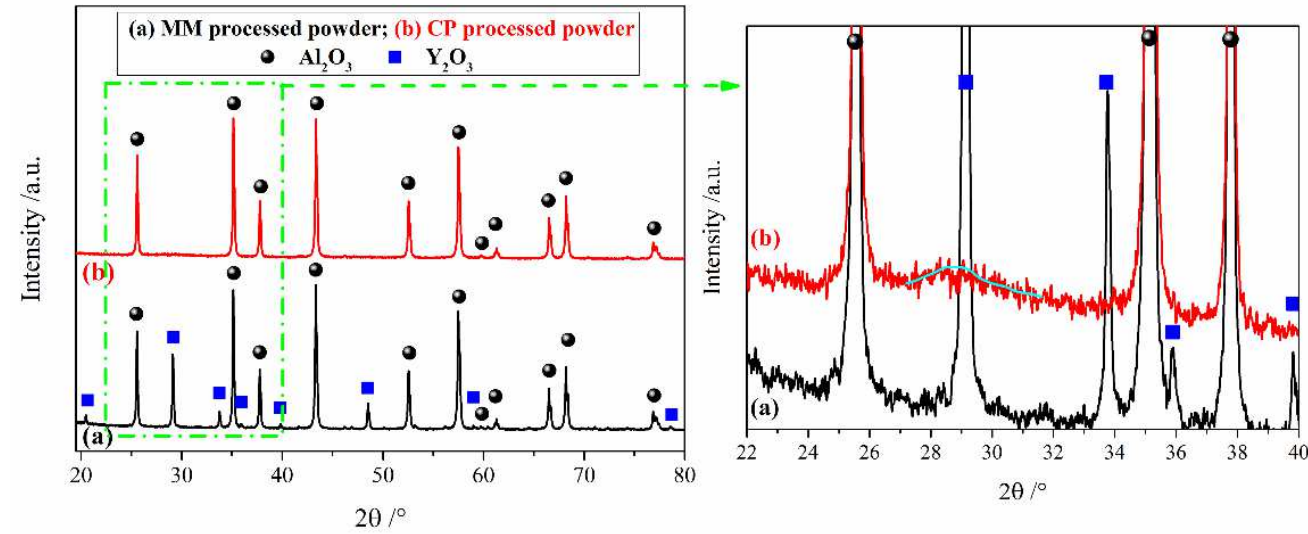

Fig. 3 XRD patterns for the MM and $\mathrm{CP}$ processed $\mathrm{Y}_{2} \mathrm{O}_{3}-\mathrm{Al}_{2} \mathrm{O}_{3}$ composite powders.

Right image is the local enlargement of left image marked by green box.

To examine the elements present and their chemical states on the ceramic powder surface, the XPS measurements of the MM and $\mathrm{CP}$ processed $\mathrm{Y}_{2} \mathrm{O}_{3}-\mathrm{Al}_{2} \mathrm{O}_{3}$ composite powders were carried out. The XPS survey scan and narrow scans of $Y_{3 d}$ are shown in Fig. 4, and the binding energies of the obtained peaks are referenced to the $\mathrm{C}_{1 \mathrm{~s}}$ signal for $\mathrm{C}-\mathrm{H}$. Both the spectra of the $\mathrm{MM}$ and $\mathrm{CP}$ processed $\mathrm{Y}_{2} \mathrm{O}_{3}-\mathrm{Al}_{2} \mathrm{O}_{3}$ powders reveal the peaks for $\mathrm{O}_{1 \mathrm{~s}}, \mathrm{Y}_{3 \mathrm{~d}}$ and $\mathrm{Al}_{2 \mathrm{p}}$, which indicates the presence of $\mathrm{O}, \mathrm{Y}$ and $\mathrm{Al}$, as shown in Fig. 4a. Figs. $4 \mathrm{~b}$ and $4 \mathrm{c}$ show the narrow scan for $\mathrm{Y}_{3 \mathrm{~d}}$ core level, and the raw data was fitted using the Thermo Advantage V5.52 software. The high-resolution $\mathrm{Y}_{3 \mathrm{~d}}$ spectrum (Figs. 4b and 4c) can be decomposed into couple of doublets related to the spin-orbit splitting of $\mathrm{Y}_{3 d} 5 / 2$ and $\mathrm{Y}_{3 d}$ 3/2. The $\mathrm{Y}_{3 d}$ 5/2 peaks locate at $157.96 \mathrm{eV}$ and $157.55 \mathrm{eV}$ for the $\mathrm{CP}$ and $\mathrm{MM}$ processed $\mathrm{Y}_{2} \mathrm{O}_{3}-\mathrm{Al}_{2} \mathrm{O}_{3}$ powders, respectively. These $Y_{3 d}$ 5/2 binding energies are in accordance with the documented values $(158.1 \mathrm{eV}$ and 
$157.4 \mathrm{eV}$ ) for $\mathrm{Y}_{3 \mathrm{~d}} 5 / 2$ of $\mathrm{Y}_{2} \mathrm{O}_{3}[53,54]$, so the $\mathrm{Y}_{3 \mathrm{~d}} 5 / 2$ in the $\mathrm{CP}$ processed $\mathrm{Y}_{2} \mathrm{O}_{3}-\mathrm{Al}_{2} \mathrm{O}_{3}$ powders can be assigned to $\mathrm{Y}^{3+}$ in $\mathrm{Y}_{2} \mathrm{O}_{3}$. The quantitative calculations from the narrow scan results of $\mathrm{Al}_{2 \mathrm{p}}, \mathrm{O}_{1 \mathrm{~s}}, \mathrm{C}_{1 \mathrm{~s}}$ and $\mathrm{Y}_{3 \mathrm{~d}}$ were performed to determine the chemical compositions of the $\mathrm{MM}$ and CP processed $\mathrm{Y}_{2} \mathrm{O}_{3}-\mathrm{Al}_{2} \mathrm{O}_{3}$ powders, as shown in Table 1 . The $\mathrm{Y} / \mathrm{Al}$ atomic ratio of the $\mathrm{CP}$ processed $\mathrm{Y}_{2} \mathrm{O}_{3}-\mathrm{Al}_{2} \mathrm{O}_{3}$ powder is calculated to be 0.2081 , which is much greater than the $\mathrm{Y} / \mathrm{Al}$ atomic ratio of the $\mathrm{MM}$ processed $\mathrm{Y}_{2} \mathrm{O}_{3}-\mathrm{Al}_{2} \mathrm{O}_{3}$ powder $(0.0023)$ and stoichiometric mixture $\left(95 \mathrm{wt} \% \mathrm{Al}_{2} \mathrm{O}_{3}+5 \mathrm{wt} \% \mathrm{Y}_{2} \mathrm{O}_{3}\right)(0.0238)$. The much higher value of the $\mathrm{Y} / \mathrm{Al}$ atomic ratio in the $\mathrm{CP}$ processed $\mathrm{Y}_{2} \mathrm{O}_{3}-\mathrm{Al}_{2} \mathrm{O}_{3}$ powder can evidence that the surface of the $\mathrm{CP}$ processed $\mathrm{Al}_{2} \mathrm{O}_{3}$ powder is enriched with $\mathrm{Y}$, i.e., $\mathrm{Y}$ is localized in the surface layer of the $\mathrm{CP}$ processed $\mathrm{Al}_{2} \mathrm{O}_{3}$ powder [55]. It can be concluded from the TEM, XRD and XPS results that the surface of the $\mathrm{Al}_{2} \mathrm{O}_{3}$ ceramic powder is covered with an amorphous $\mathrm{Y}_{2} \mathrm{O}_{3}$ layer prepared by the $\mathrm{CP}$ process.
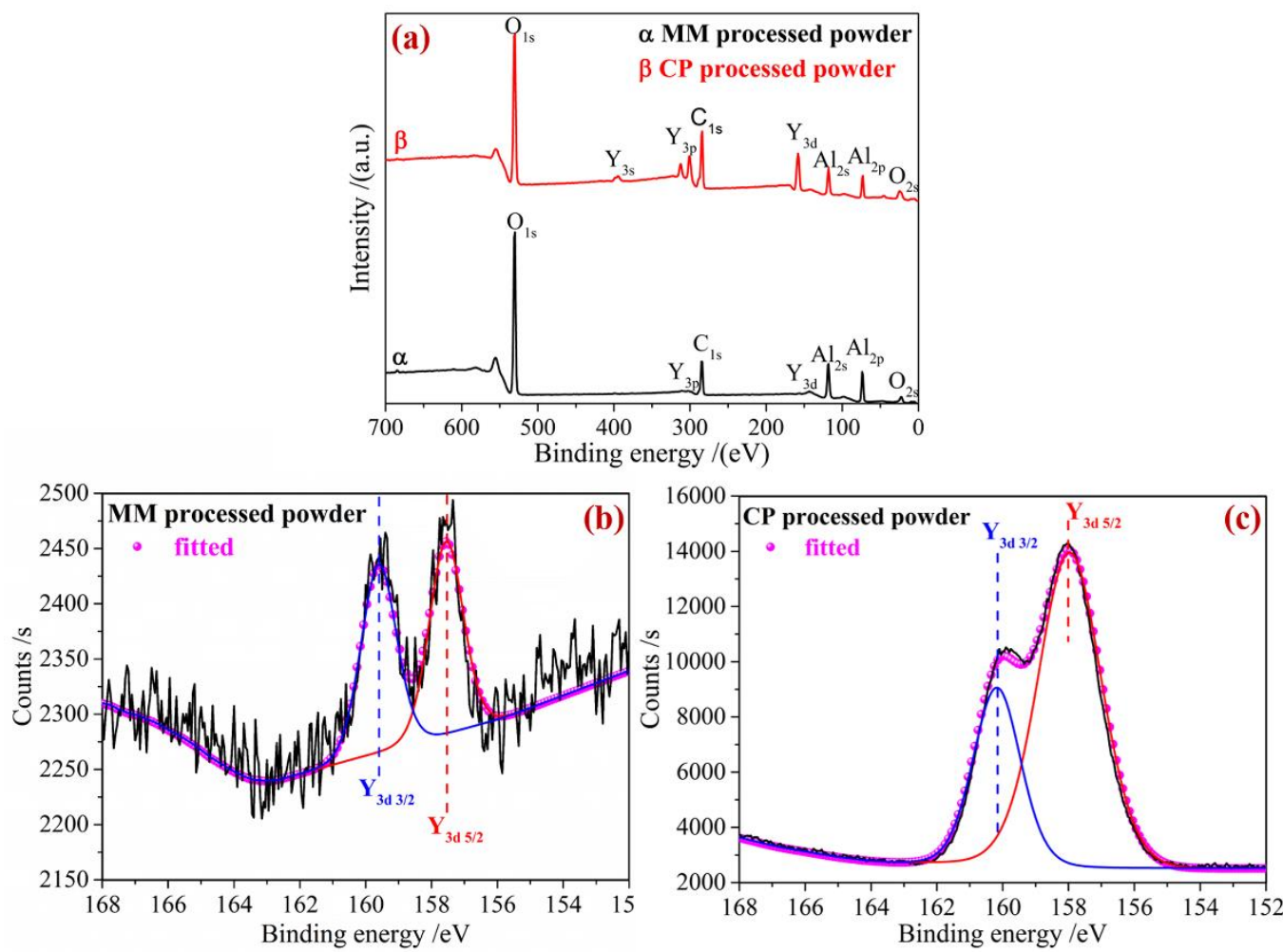

Fig. 4 (a) XPS survey scan of the MM and CP processed $\mathrm{Y}_{2} \mathrm{O}_{3}-\mathrm{Al}_{2} \mathrm{O}_{3}$ powders; (b) and 
(c) respective XPS core level spectra of $\mathrm{Y}_{3 \mathrm{~d}}$ in the $\mathrm{MM}$ and $\mathrm{CP}$ processed $\mathrm{Y}_{2} \mathrm{O}_{3}-\mathrm{Al}_{2} \mathrm{O}_{3}$ powders.

Table 1 Chemical compositions (at $\%$ ) of the $\mathrm{MM}$ and $\mathrm{CP}$ processed $\mathrm{Y}_{2} \mathrm{O}_{3}-\mathrm{Al}_{2} \mathrm{O}_{3}$ powders

\begin{tabular}{ccccr}
\hline Sample & $\mathrm{C}_{1 \mathrm{~s}}$ & $\mathrm{O}_{1 \mathrm{~s}}$ & $\mathrm{Al}_{2 \mathrm{p}}$ & $\mathrm{Y}_{3 \mathrm{~d}}$ \\
\hline $\mathrm{MM}$ processed $\mathrm{Y}_{2} \mathrm{O}_{3}-\mathrm{Al}_{2} \mathrm{O}_{3}$ powder & 24.88 & 44.76 & 30.29 & 0.07 \\
CP processed $\mathrm{Y}_{2} \mathrm{O}_{3}-\mathrm{Al}_{2} \mathrm{O}_{3}$ powder & 36.62 & 39.52 & 19.75 & 4.11 \\
\hline
\end{tabular}

\subsection{Phase analysis and microstructure of sintered $\mathrm{Al}_{2} \mathrm{O}_{3}$ ceramics}

The XRD patterns of the 3D printed $\mathrm{Al}_{2} \mathrm{O}_{3}$ ceramic samples are shown in Fig. 5, and the peak intensities are normalized relative to the $\mathrm{Al}_{2} \mathrm{O}_{3}$ (211). Diffraction peaks of $\alpha-\mathrm{Al}_{2} \mathrm{O}_{3}$, as the only phase for Sample AL, are exhibited in Fig. 5 (a). The XRD patterns of Samples MM and $\mathrm{CP}$ show $\alpha-\mathrm{Al}_{2} \mathrm{O}_{3}$ and $\mathrm{Y}_{3} \mathrm{Al}_{5} \mathrm{O}_{12}(\mathrm{YAG})$ as the primary and minor phase, respectively. With the addition of $\mathrm{Y}_{2} \mathrm{O}_{3}$ into $\mathrm{Al}_{2} \mathrm{O}_{3}$, the $\mathrm{YAG}$ phase is generated by a series of reactions as follows $[56,57]:$

$$
\begin{aligned}
& \mathrm{Al}_{2} \mathrm{O}_{3}+2 \mathrm{Y}_{2} \mathrm{O}_{3}=\mathrm{Y}_{4} \mathrm{Al}_{2} \mathrm{O}_{9} \\
& \mathrm{Y}_{4} \mathrm{Al}_{2} \mathrm{O}_{9}+\mathrm{Al}_{2} \mathrm{O}_{3}=4 \mathrm{YAlO}_{3} \\
& 3 \mathrm{YAlO}_{3}+\mathrm{Al}_{2} \mathrm{O}_{3}=\mathrm{Y}_{3} \mathrm{Al}_{5} \mathrm{O}_{12}
\end{aligned}
$$

Combining the above reaction equations, a simplified expression can be obtained:

$$
5 \mathrm{Al}_{2} \mathrm{O}_{3}+3 \mathrm{Y}_{2} \mathrm{O}_{3}=2 \mathrm{Y}_{3} \mathrm{Al}_{5} \mathrm{O}_{12}
$$

Based on the Eq. (8), $5 \mathrm{wt} \%$ of $\mathrm{Y}_{2} \mathrm{O}_{3}$ can react with $3.76 \mathrm{wt} \% \mathrm{Al}_{2} \mathrm{O}_{3}$ to form $\mathrm{Y}_{3} \mathrm{Al}_{5} \mathrm{O}_{12}$ in the $5 \mathrm{wt} \% \mathrm{Y}_{2} \mathrm{O}_{3}-95 \mathrm{wt} \% \mathrm{Al}_{2} \mathrm{O}_{3}$ system, thus the theoretical mass percentages of $\mathrm{Y}_{3} \mathrm{Al}_{5} \mathrm{O}_{12}$ 
and $\mathrm{Al}_{2} \mathrm{O}_{3}$ in the sintered ceramic are calculated to be $8.76 \mathrm{wt} \%$ and $91.24 \mathrm{wt} \%$, respectively. The content of each phase in the prepared ceramic samples was estimated by the RIR analysis from the X-ray diffraction data and the result is listed in Table 2. It can be seen that the contents of $\mathrm{Y}_{3} \mathrm{Al}_{5} \mathrm{O}_{12}$ in Samples MM and CP are $8.16 \mathrm{wt} \%$ and $8.74 \mathrm{wt} \%$, respectively, which are basically coincident with the theoretical calculation value. This result indicates that the $\mathrm{Y}_{2} \mathrm{O}_{3}$ had been completely reacted with $\mathrm{Al}_{2} \mathrm{O}_{3}$ in Samples $\mathrm{MM}$ and $\mathrm{CP}$ by high temperature sintering. Moreover, the calculated mass fraction of each phase can be used to determine the specific heat capacities of Samples MM and CP via the Eq. (2).

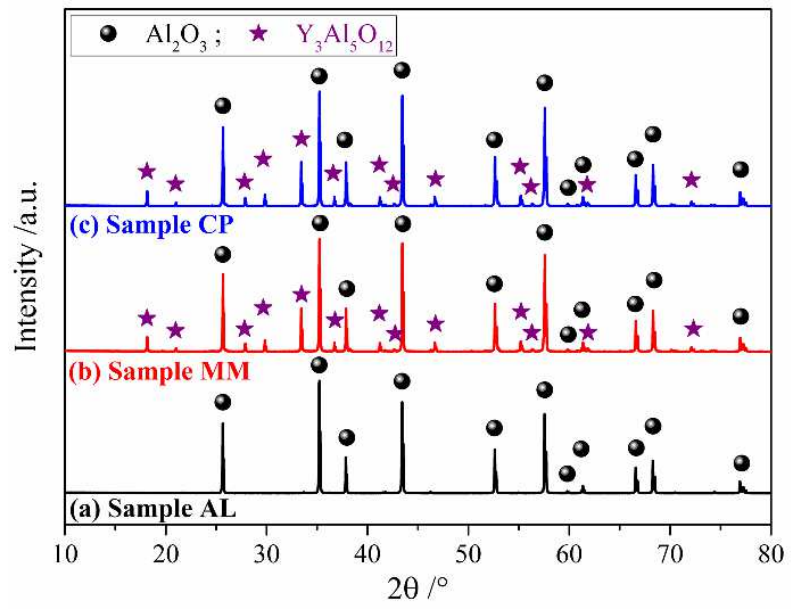

Fig. 5 XRD patterns for the prepared $\mathrm{Al}_{2} \mathrm{O}_{3}$ ceramic samples.

Table 2 Phase content in the prepared $\mathrm{Al}_{2} \mathrm{O}_{3}$ ceramics estimated by the semiquantitative method

\begin{tabular}{ccc|cc}
\hline \multirow{2}{*}{ Sample } & \multicolumn{2}{c|}{$\begin{array}{c}\text { Semi-quantitative phase } \\
\text { content in ceramics } / \mathrm{wt} \%\end{array}$} & \multicolumn{2}{c}{$\begin{array}{c}\text { Semi-quantitative phase content } \\
\text { in ceramics } / \text { vol\% }\end{array}$} \\
\cline { 2 - 5 } & $\mathrm{Al}_{2} \mathrm{O}_{3}$ & $\mathrm{Y}_{3} \mathrm{Al}_{5} \mathrm{O}_{12}$ & $\mathrm{Al}_{2} \mathrm{O}_{3}$ & $\mathrm{Y}_{3} \mathrm{Al}_{5} \mathrm{O}_{12}$ \\
\hline $\mathrm{AL}$ & 100.00 & 0 & 100.00 & 0 \\
$\mathrm{MM}$ & 91.84 & 8.16 & 92.79 & 7.21 \\
$\mathrm{CP}$ & 91.26 & 8.74 & 92.27 & 7.73 \\
\hline
\end{tabular}


Figure 6 demonstrates the SEM observation on the microstructures of different sintered $\mathrm{Al}_{2} \mathrm{O}_{3}$ samples and their grain size distributions. In this figure, the white zone at grain boundary areas corresponds to the $\mathrm{Y}_{3} \mathrm{Al}_{5} \mathrm{O}_{12}$ second phase (as shown in Fig. 5), while the gray and black sections are $\mathrm{Al}_{2} \mathrm{O}_{3}$ grains and pores, respectively. Compared with Sample AL (Fig. 6a), Samples MM and CP (Figs. $6 \mathrm{~b}$ and $6 \mathrm{c}$ ) possess higher porosities, corresponding to the relatively higher density of Samples AL as shown in Table 3. It suggests that the densification of $\mathrm{Al}_{2} \mathrm{O}_{3}$ matrix was slightly inhibited by the addition of $5 \mathrm{wt} \%$ of $\mathrm{Y}_{2} \mathrm{O}_{3}$. On the one hand, the yttrium segregation at $\mathrm{Al}_{2} \mathrm{O}_{3} / \mathrm{Al}_{2} \mathrm{O}_{3}$ interfaces can block the diffusion of ions along grain boundaries, leading to a reduced grain boundary diffusivity and hence a decreased densification rate $[33,34,58]$. On the other hand, once above the $\mathrm{Y}_{2} \mathrm{O}_{3}$ solubility-limit in $\mathrm{Al}_{2} \mathrm{O}_{3}$, the extra $\mathrm{Y}_{2} \mathrm{O}_{3}$ would react with $\mathrm{Al}_{2} \mathrm{O}_{3}$ matrix and then form $\mathrm{Y}_{3} \mathrm{Al}_{5} \mathrm{O}_{12}$ precipitations via the solid state reactions (Eqs. $5 \sim 7$ ). The $\mathrm{Y}_{3} \mathrm{Al}_{5} \mathrm{O}_{12}$ precipitations, present at grain boundaries and multigrain junctions in $\mathrm{Al}_{2} \mathrm{O}_{3}$ matrix, can result in Zener pinning action on grain boundary mobility and finally retarding the densification of $\mathrm{Al}_{2} \mathrm{O}_{3}$ matrix $[59,60]$.

As shown in Fig. 6a, the 3D printed monolithic $\mathrm{Al}_{2} \mathrm{O}_{3}$ ceramic possesses an obvious coarsening and inhomogeneous microstructure (grain size up to $4.78 \mu \mathrm{m}$, and with a low Christiansen uniformity coefficient of 0.50 ). The introduction of $\mathrm{Y}_{2} \mathrm{O}_{3}$ enables the $\mathrm{Al}_{2} \mathrm{O}_{3}$ matrix grain size to be refined, due to the pinning effect of $\mathrm{Y}_{3} \mathrm{Al}_{5} \mathrm{O}_{12}$ precipitations $[33,59]$. The mean grain sizes of Samples MM and CP are smaller than that in Sample AL by $26.78 \%$ and $64.44 \%$, respectively. Furthermore, the grain size of Sample CP $(\sim 1.70 \mu \mathrm{m})$ is $51.43 \%$ 
smaller than that of Sample MM $(\sim 3.50 \mu \mathrm{m})$. It suggests that the different introducing ways of $\mathrm{Y}_{2} \mathrm{O}_{3}$ would result in different growth trends for the $\mathrm{Al}_{2} \mathrm{O}_{3}$ grains. Compared to Sample MM, Sample CP shows much refined $\mathrm{Y}_{3} \mathrm{Al}_{5} \mathrm{O}_{12}$ precipitations and an increased degree of $\mathrm{Y}_{3} \mathrm{Al}_{5} \mathrm{O}_{12}$ distribution range at grain boundary areas in the matrix. This precipitation feature displayed in Samples CP can lead to more areas of Zener pinning on grain boundary migration, and hence enable a much refined and homogenous $\mathrm{Al}_{2} \mathrm{O}_{3}$ matrix microstructure. By way of illustration, in both Ref. [24] and present work, the same $\mathrm{Al}_{2} \mathrm{O}_{3}$ powder was used; although the sintering temperature $\left(1600{ }^{\circ} \mathrm{C}\right)$ in Ref. [24] is lower than that $\left(1650{ }^{\circ} \mathrm{C}\right)$ in the present work, the grain size of Sample CP is much less than the value reported in that work $(2.6 \mu \mathrm{m})$ [24]. The microstructure refinement is often expected to fabricate $\mathrm{Al}_{2} \mathrm{O}_{3}$ ceramic with higher strength according to the Hall-Petch relationship [61]. Furthermore, Sample CP has the narrowest grain size distribution, with a Christiansen uniformity coefficient of 0.70 , which is $12.90 \%$ and $40.00 \%$ higher than those of Samples MM and AL, respectively. This finding demonstrates that the $\mathrm{CP}$ process can make the microstructure of $\mathrm{Al}_{2} \mathrm{O}_{3}$ ceramic more uniform, which can play a crucial role in improving the reliability of $\mathrm{Al}_{2} \mathrm{O}_{3}$ ceramics. 

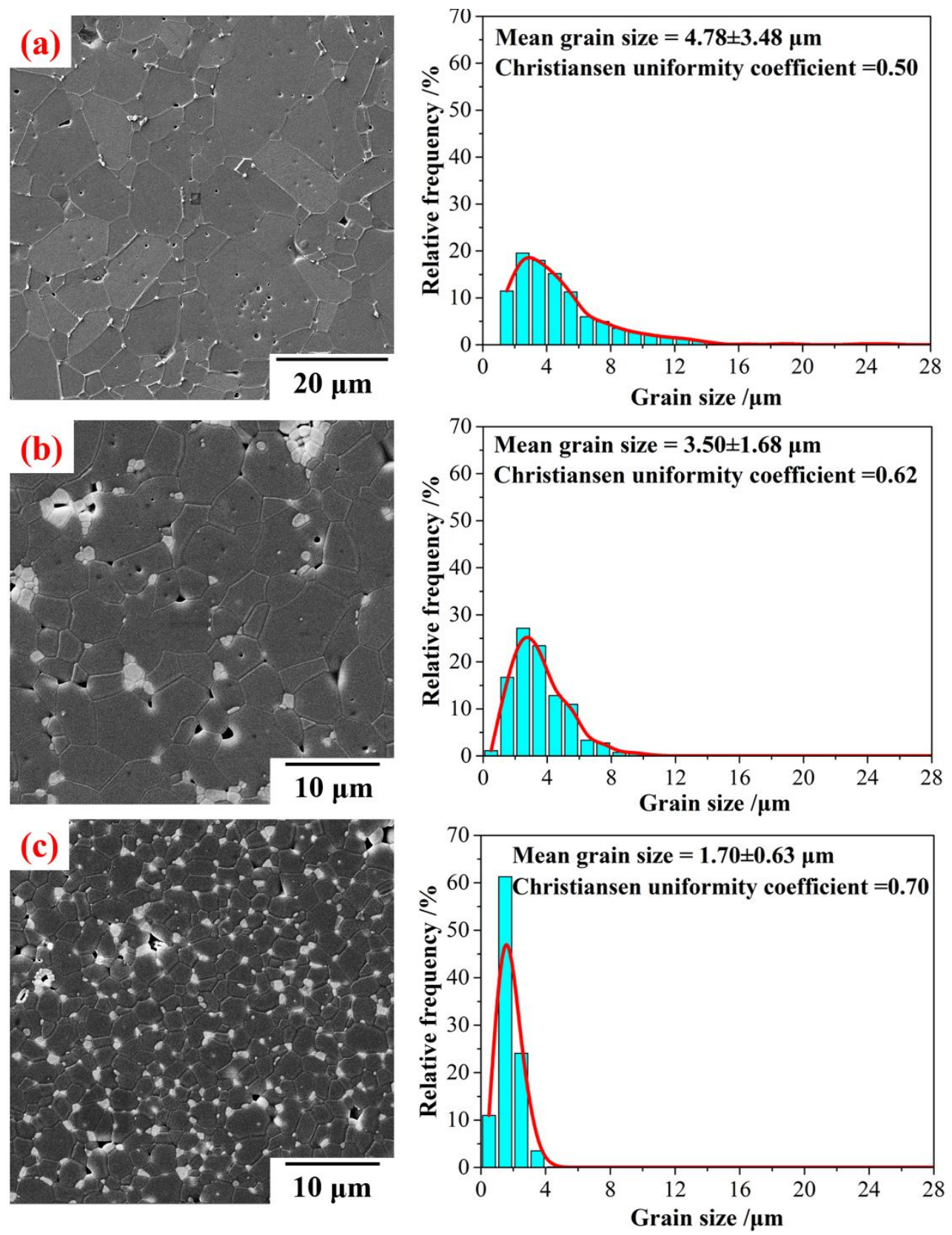

Fig. 6 Microstructures and grain size statistics of (a) Sample AL, (b) Sample MM and

(c) Sample CP.

\subsection{Properties of 3D printed $\mathrm{Al}_{2} \mathrm{O}_{3}$ ceramics}

The mechanical and thermal properties of the 3D printed $\mathrm{Al}_{2} \mathrm{O}_{3}$ ceramics are listed in

Table 3. The relative density of pure $\mathrm{Al}_{2} \mathrm{O}_{3}$ ceramic (Sample AL) is higher than those of $\mathrm{Y}_{2} \mathrm{O}_{3}-$ 
$\mathrm{Al}_{2} \mathrm{O}_{3}$ system (Samples $\mathrm{MM}$ and $\mathrm{CP}$ ), demonstrating that the addition of $5 \mathrm{wt} \%$ of $\mathrm{Y}_{2} \mathrm{O}_{3}$ is detrimental for the densification of $\mathrm{Al}_{2} \mathrm{O}_{3}$ ceramic. In addition, Sample $\mathrm{CP}$ has a higher relative density than Sample MM, which is consistent with the denser microstructure of Sample CP (Fig. 6c) compared to that of Sample MM (Fig. 6b), illustrating that the CP process can improve the relative density of the $\mathrm{Y}_{2} \mathrm{O}_{3}-\mathrm{Al}_{2} \mathrm{O}_{3}$ system compared with the conventional MM process.

Table 3 Mechanical and thermal properties of the $3 \mathrm{D}$ printed $\mathrm{Al}_{2} \mathrm{O}_{3}$ ceramics

\begin{tabular}{cccc}
\hline Sample & $\begin{array}{c}\text { Relative density } \\
/ \%\end{array}$ & $\begin{array}{c}\text { Flexural strength } \\
/ \mathrm{MPa}\end{array}$ & $\begin{array}{c}\text { Thermal conductivity } \\
/ \mathrm{W} \cdot \mathrm{m}^{-1} \cdot \mathrm{K}^{-1}\end{array}$ \\
\hline $\mathrm{AL}$ & $98.19 \pm 0.12$ & $362.98 \pm 28.61$ & $33.40 \pm 1.51$ \\
$\mathrm{MM}$ & $97.31 \pm 0.23$ & $396.50 \pm 46.84$ & $29.16 \pm 0.55$ \\
$\mathrm{CP}$ & $97.53 \pm 0.15$ & $455.37 \pm 32.17$ & $28.95 \pm 0.28$ \\
\hline
\end{tabular}

As displayed in Table 3, Sample AL has the lowest flexural strength, which is $8.45 \%$ and $20.29 \%$ lower than those of Samples MM and CP, respectively, i.e., the addition of $\mathrm{Y}_{2} \mathrm{O}_{3}$ is favorable to the improvement of flexural strength of the $3 \mathrm{D}$ printed $\mathrm{Al}_{2} \mathrm{O}_{3}$ ceramic. The improved flexural strength of the $\mathrm{Y}_{2} \mathrm{O}_{3}-\mathrm{Al}_{2} \mathrm{O}_{3}$ system is resulted from the fine grain strengthening and dispersion strengthening of the $\mathrm{Y}_{3} \mathrm{Al}_{5} \mathrm{O}_{12}$ particles $[62,63]$. The flexural strength of Sample CP is $14.85 \%$ higher than that of Sample MM, owing to the finer $\mathrm{Al}_{2} \mathrm{O}_{3}$ grain and more homogeneous microstructure of Sample CP (as shown in Fig. 6c); also the relative density improvement can lead to an increase in flexural strength of Sample CP, according to the empirical suggestion for the strength of ceramics [1]. Fracture surface SEM micrographs of the 3D printed ceramic samples are shown in Fig. 7. Fractures predominantly 
occurred in an intergranular mode for Samples AL and MM (Figs. 7a and 7b). On the other hand, a large proportion of $\mathrm{Al}_{2} \mathrm{O}_{3}$ grains fractured transgranularly in Sample CP (Fig. 7c). This indicates that the $\mathrm{Al}_{2} \mathrm{O}_{3}$ grain boundaries in Sample CP should be much stronger than those in Samples AL and MM, leading to the increased flexural strength for Sample CP.
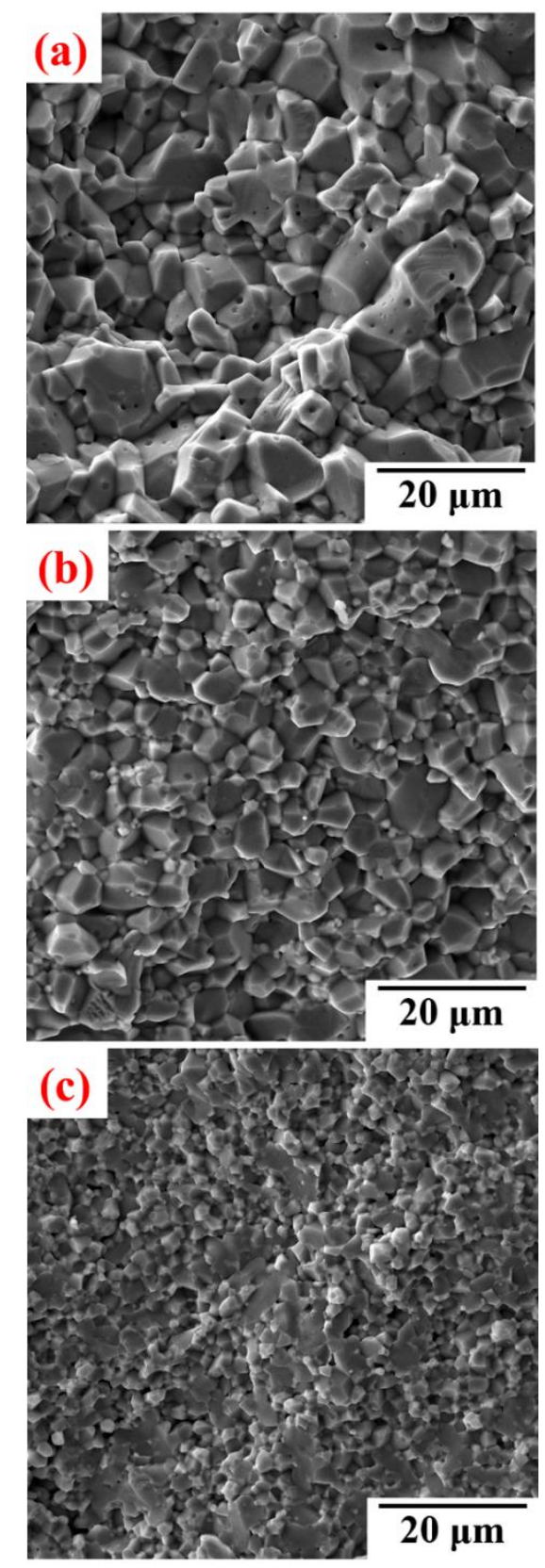

Fig. 7 SEM micrographs of the fracture surfaces of (a) Sample AL, (b) Sample MM and (c) Sample CP. 
Furthermore, reliability analysis was conducted by estimating the Weibull modulus of the flexural strength distribution using at least 16 samples [64]. The two-parameter Weibull distribution was calculated by the equation:

$$
\ln \ln \left(\frac{1}{1-P_{f}}\right)=m \ln \sigma_{n}-m \ln \sigma_{0}
$$

where $P_{\mathrm{f}}=(n-0.5) / \mathrm{N}$ is an estimator of the fracture probability of the $n$th ranked sample, $n$ is the rank of the bending strength data, $\mathrm{N}$ is the total number of samples tested $(\mathrm{N}=16$ in the present work), $m$ is the Weibull modulus, $\sigma_{n}$ is the measured bending strength and $\sigma_{0}$ is the Weibull material scale parameter [64]. A higher $m$ value means a better uniformity of flexural strength and a higher reliability of ceramic. The flexural strength distribution of Samples AL, MM and CP is shown in Fig. 8. The Weibull modulus for Sample MM is $35.33 \%$ lower than that for Sample AL, illustrating that the introduction of $\mathrm{Y}_{2} \mathrm{O}_{3}$ into $\mathrm{Al}_{2} \mathrm{O}_{3}$ via the conventional $\mathrm{MM}$ process can decrease the reliability of $\mathrm{Al}_{2} \mathrm{O}_{3}$ ceramic. The agglomeration of $\mathrm{Y}_{3} \mathrm{Al}_{5} \mathrm{O}_{12}$ second (as shown in Fig. 6b) can make the homogeneity of Sample MM deterioration, thus leading the reduction of Weibull modulus. Compared to the Weibull modulus for Sample MM, a very drastic increase from 9.59 to 16.88 in the Weibull modulus for Sample CP was obtained, indicating a much higher reliability and repeatability. These above findings illustrate that the $\mathrm{CP}$ process is beneficial to simultaneously enhance the flexural strength and reliability of the $3 \mathrm{D}$ printed $\mathrm{Al}_{2} \mathrm{O}_{3}$ ceramic. 


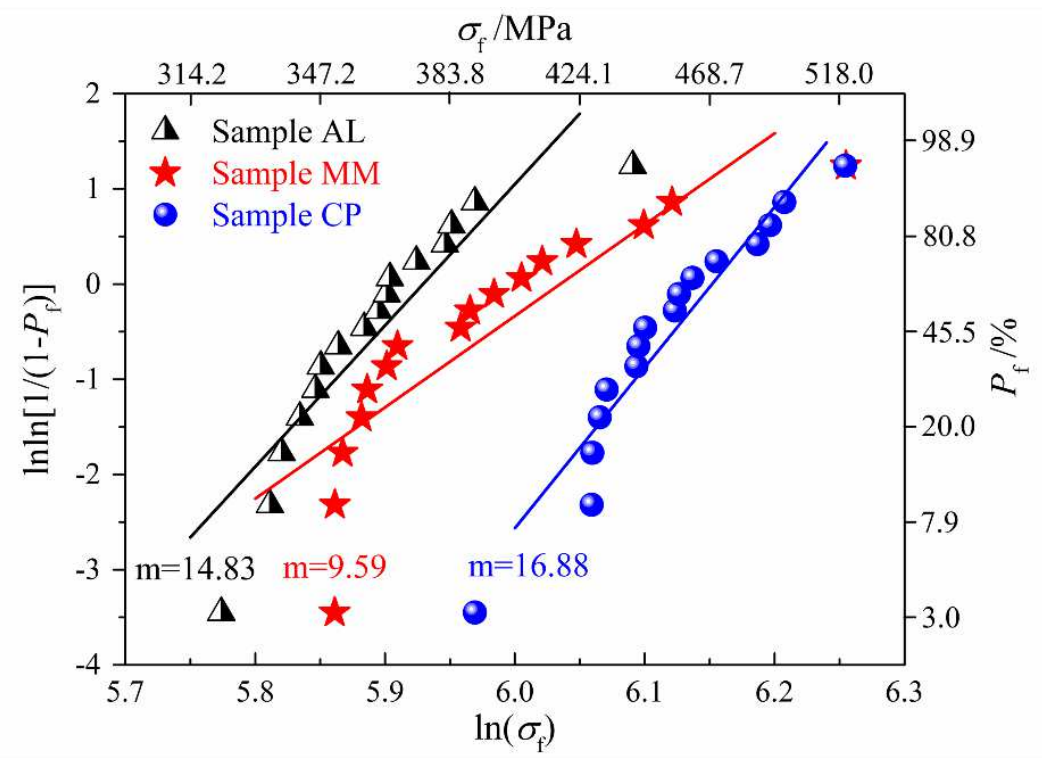

Fig. 8 Weibull plots for the flexural strength of Samples AL, MM and CP.

It can be seen from Table 3 that the thermal conductivity of pure $\mathrm{Al}_{2} \mathrm{O}_{3}$ ceramic (Sample AL) is $14.54 \%$ and $15.37 \%$ higher than those of Samples $\mathrm{MM}$ and $\mathrm{CP}\left(\mathrm{Y}_{2} \mathrm{O}_{3}-\mathrm{Al}_{2} \mathrm{O}_{3}\right.$ system), respectively. The addition of $5 \mathrm{wt} \%$ of $\mathrm{Y}_{2} \mathrm{O}_{3}$ causes a fall in thermal conductivity compared with that of pure $\mathrm{Al}_{2} \mathrm{O}_{3}$ and this is accompanied by the decreased relative density and formation of second phase $\left(\mathrm{Y}_{3} \mathrm{Al}_{5} \mathrm{O}_{12}\right)$. The pores and second phases can enhance phonon scattering and decrease the effective conductive mean free path, therefor reduce the thermal conductivity according to the kinetic theory of phonons in solids $[65,66]$. Based on the Maxwell model, the thermal conductivity of ceramic sample with isolated pores dispersed in a ceramic matrix is written as [67]:

$$
\lambda=\lambda_{0} \cdot \frac{2(1-\varphi)}{2+\varphi}
$$

where $\lambda$ is the apparent thermal conductivity of ceramic with pores, $\varphi$ is the porosity of ceramic and $\varphi=1-R D \%$ (relative density), and $\lambda_{0}$ is the thermal conductivity of completely 
dense ceramic without pore $(\varphi=0)$. By substituting the measured thermal conductivity and relative density of Sample AL into Eq. (10), the thermal conductivity of the dense $\mathrm{Al}_{2} \mathrm{O}_{3}$ ceramic is calculated to be $34.32 \mathrm{~W} \cdot \mathrm{m}^{-1} \cdot \mathrm{K}^{-1}$, which is in accordance with the documental values $\left(33 \pm 2 \mathrm{~W} \cdot \mathrm{m}^{-1} \cdot \mathrm{K}^{-1}\right.$, ) for pure dense $\mathrm{Al}_{2} \mathrm{O}_{3}$ at ambient temperature [47]. From the mathematical analysis by Eq. (10), the increase of porosity can result in a drop in thermal conductivity. Thus the $\mathrm{Y}_{2} \mathrm{O}_{3}-\mathrm{Al}_{2} \mathrm{O}_{3}$ system with lower relative density has a thermal conductivity inferior to the denser pure $\mathrm{Al}_{2} \mathrm{O}_{3}$ ceramic.

The component and structure of composite material has a significant effect on the thermal conductivity [68]. For $\mathrm{Y}_{2} \mathrm{O}_{3}-\mathrm{Al}_{2} \mathrm{O}_{3}$ composite system $\left(\mathrm{Al}_{2} \mathrm{O}_{3}\right.$ ceramic with a small amount of $\mathrm{Y}_{3} \mathrm{Al}_{5} \mathrm{O}_{12}$ second phase), the Maxwell-Eucken (ME) model can be used to predict the thermal conductivity via the following relation [69-71]:

$$
\lambda_{\mathrm{c}}=\lambda_{\mathrm{s}} \cdot \frac{2 \lambda_{\mathrm{s}}+\lambda_{\mathrm{p}}+2 V_{\mathrm{p}}\left(\lambda_{\mathrm{p}}-\lambda_{\mathrm{s}}\right)}{2 \lambda_{\mathrm{s}}+\lambda_{\mathrm{p}}-V_{\mathrm{p}}\left(\lambda_{\mathrm{p}}-\lambda_{\mathrm{s}}\right)}
$$

where $\lambda_{\mathrm{c}}, \lambda_{\mathrm{s}}$ and $\lambda_{\mathrm{p}}$ are the thermal conductivities of the composite ceramic, $\mathrm{Al}_{2} \mathrm{O}_{3}$ and $\mathrm{Y}_{3} \mathrm{Al}_{5} \mathrm{O}_{12}$ phase, respectively, and $V_{\mathrm{p}}$ is the volume fraction of $\mathrm{Y}_{3} \mathrm{Al}_{5} \mathrm{O}_{12}$ phase. In the present work, a value of $\lambda_{\mathrm{p}}=10.7 \mathrm{~W} \cdot \mathrm{m}^{-1} \cdot \mathrm{K}^{-1}$ was used for the thermal conductivity of pure $\mathrm{Y}_{3} \mathrm{Al}_{5} \mathrm{O}_{12}$ phase [72], which is much lower than the thermal conductivity of dense $\mathrm{Al}_{2} \mathrm{O}_{3}$ ceramic (34.32 $\left.\mathrm{W} \cdot \mathrm{m}^{-1} \cdot \mathrm{K}^{-1}\right)$. If the morphology of second phase is not completely isolated, the effect of the connectivity of second phase on the thermal conductivity of composite system cannot be ignored. An appropriate model is given by the effective medium theory (EMT), and the thermal conductivity of composite system is given by $[69,73]$ : 


$$
\lambda_{\mathrm{c}}=\frac{1}{4}\left\{\lambda_{\mathrm{p}}\left(3 V_{\mathrm{p}}-1\right)+\lambda_{\mathrm{s}}\left(2-3 V_{\mathrm{p}}\right)+\left[\left(3 \lambda_{\mathrm{p}} V_{\mathrm{p}}-\lambda_{\mathrm{p}}+2 \lambda_{\mathrm{s}}-3 \lambda_{\mathrm{s}} V_{\mathrm{p}}\right)^{2}+8 \lambda_{\mathrm{p}} \lambda_{\mathrm{s}}\right]^{\frac{1}{2}}\right\}
$$

The calculated thermal conductivities derived from Eqs. (10), (11) and (12) are shown in Table 4. The formation of $\mathrm{Y}_{3} \mathrm{Al}_{5} \mathrm{O}_{12}$ precipitations with a low thermal conductivity can result in a drop in thermal conductivity of $\mathrm{Y}_{2} \mathrm{O}_{3}-\mathrm{Al}_{2} \mathrm{O}_{3}$ system based on the ME and EMT model analyses. However, the thermal conductivities of $\mathrm{Y}_{2} \mathrm{O}_{3}-\mathrm{Al}_{2} \mathrm{O}_{3}$ system estimated by the $\mathrm{ME}$ and EMT models are higher than the measured values of thermal conductivities of Samples MM and $\mathrm{CP}$ since the phonon scattering caused by the pores, second phase precipitations and grain boundaries can decrease the phonon mean free path and further lead to the reduction of thermal conductivity $[66,69]$. Thus, the addition of $\mathrm{Y}_{2} \mathrm{O}_{3}$ into $\mathrm{Al}_{2} \mathrm{O}_{3}$ is expected to reduce the thermal conductivity of $3 \mathrm{D}$ printed $\mathrm{Al}_{2} \mathrm{O}_{3}$ ceramic.

Table 4 A comparison between the calculated and measured thermal conductivities of

\begin{tabular}{cccccccc}
\multicolumn{8}{c}{$\mathrm{Y}_{2} \mathrm{O}_{3}-\mathrm{Al}_{2} \mathrm{O}_{3}$ system } \\
$\begin{array}{c}\text { Calculation } \\
\text { model }\end{array}$ & Sample & $\lambda_{\mathrm{s}}$ & $\lambda_{\mathrm{p}}$ & $\lambda_{\mathrm{c} 0}$ & $\varphi$ & $\lambda_{\text {c-calculated }}$ & $\lambda_{\text {c-measured }}$ \\
\hline \multirow{2}{*}{$\mathrm{ME}$} & $\mathrm{MM}$ & 34.32 & 10.70 & 32.16 & $2.69 \%$ & 30.88 & 29.16 \\
& $\mathrm{CP}$ & 34.32 & 10.70 & 32.00 & $2.47 \%$ & 30.83 & 28.95 \\
\hline \multirow{2}{*}{ EMT } & $\mathrm{MM}$ & 34.32 & 10.70 & 32.13 & $2.69 \%$ & 30.85 & 29.16 \\
& $\mathrm{CP}$ & 34.32 & 10.70 & 31.97 & $2.47 \%$ & 30.80 & 28.95 \\
\hline
\end{tabular}

The grain boundaries can act as the scattering sites for phonons and reduce the thermal conductivity of ceramic [69]. This reduction can be enhanced by decreasing the grain size, which is attributed to the increased number of grain boundaries per unit length of heat path. However, compared to the coarse grained Sample MM, the fine grained Sample CP has a 
similar value of thermal conductivity, rather than a lower value, as shown in Table 3 , because the thermal conductivity of ceramic is also highly affected by second phase morphology [42]. The SEM image and corresponding EDS mapping for $\mathrm{Y}$ on the fracture surfaces of Sample MM sintered at $1650{ }^{\circ} \mathrm{C}$ are shown in Figs. 9a1 and 9a2. Sample MM has large $\mathrm{Y}$ patches distributed heterogeneously (Fig. 9a2), and these patches are on the average size of $2.85 \pm 1.24$ $\mu \mathrm{m}$, which is comparable to the grain size of Sample MM $(3.50 \pm 1.68 \mu \mathrm{m})$, manifesting an apparent agglomeration of $\mathrm{Y}_{3} \mathrm{Al}_{5} \mathrm{O}_{12}$ phase during sintering. A presence of semi-connected $\mathrm{Y}_{3} \mathrm{Al}_{5} \mathrm{O}_{12}$ aggregates can be observed in Fig. 9a3, and the $\mathrm{Y}_{3} \mathrm{Al}_{5} \mathrm{O}_{12}$ aggregates distributes continuously along $\mathrm{Al}_{2} \mathrm{O}_{3}$ grain boundaries in Sample MM. The second phased distribution of Sample CP sintered at $1650^{\circ} \mathrm{C}$ is shown in Figs. $9 \mathrm{~b} 1 \sim 9 \mathrm{~b} 3$. Sample $\mathrm{CP}$ has small Y patches distributed homogeneously (Fig. 9b2), and these patches are on the average size of $0.71 \pm 0.26$ $\mu \mathrm{m}$, which is much lower than the grain size of Sample CP $(1.70 \pm 0.63 \mu \mathrm{m})$; Combined with the results obtained from SEM micrograph of Sample CP (Fig. 6c), the small-sized $\mathrm{Y}_{3} \mathrm{Al}_{5} \mathrm{O}_{12}$ particles tend to be concentrated at multigrain junctions without continuous distribution along $\mathrm{Al}_{2} \mathrm{O}_{3}$ grain boundaries. The morphologic change of the second phase from semi-connected (Sample MM) to isolated (Sample CP) can contribute to an improvement of the thermal conductivity of $\mathrm{Al}_{2} \mathrm{O}_{3}$ ceramics, according to the comparison between EMT model (Eq. 12) for the interconnected second phase and ME model (Eq. 11) for the isolated second phase [42, 68]. In addition, compared to Sample MM, the higher relative density of Sample CP can lead to an increase in thermal conductivity. From all the above analysis, Sample CP has a close thermal conductivity to Sample MM due to the combined contribution of grain size, second 
phase morphology and relative density.
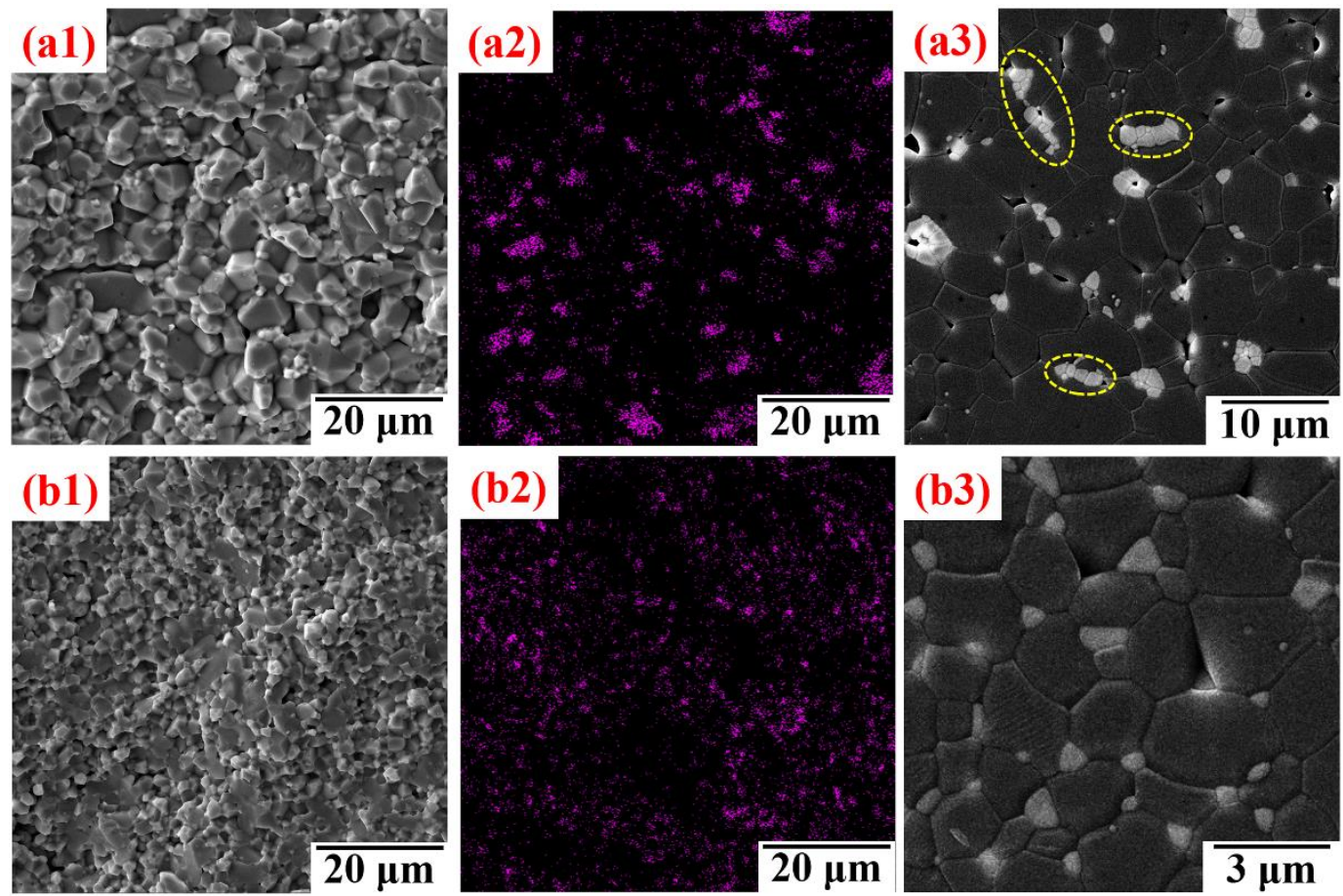

Fig. 9 SEM images and corresponding EDS mappings for $\mathrm{Y}$ on the fracture surfaces of

Sample MM (a1, a2) and Sample CP (b1, b2); SEM micrographs of the polished and etched surfaces of Sample MM (a3) and Sample CP (b3). The semi-connected second phases are marked with red circles.

According to the above research results, the CP process is an effective method to enhance the flexural strength and reliability of $3 \mathrm{D}$ printed $\mathrm{Al}_{2} \mathrm{O}_{3}$ ceramic. Typical $\mathrm{Al}_{2} \mathrm{O}_{3}$ ceramic components with complex shapes can be fabricated by a novel approach integrating DLPstereolithography and CP process, as shown in Fig. 10. The surface smoothness of the fabricated parts appears to be fine. The pin-type heat sinks with different fin configuration are shown in Fig. 10, which shows potential application in thermal management in electronics and automotive industries [74]. Therefore, the fundamental study of this paper can offer an alternative approach to fabricate ceramic heat sinks with complex shapes and excellent 
mechanical performance.

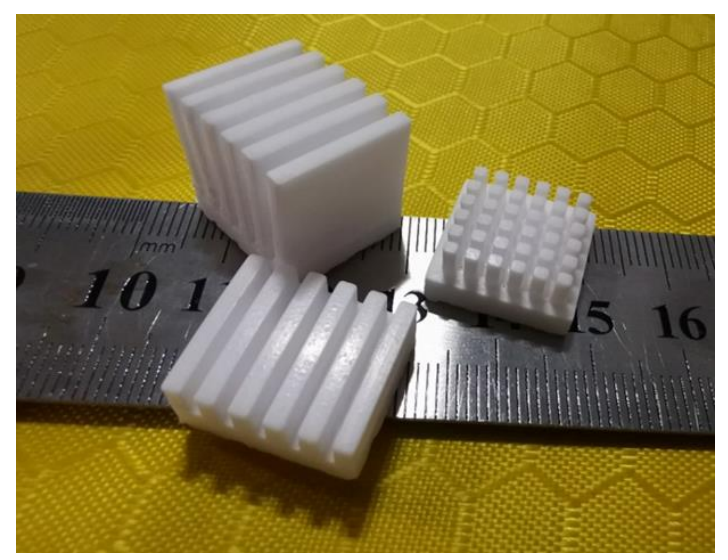

Fig. 10 Optical image of fin-type $\mathrm{Al}_{2} \mathrm{O}_{3}$ ceramic heat sinks fabricated by a novel approach integrating DLP-stereolithography and CP process.

\section{Conclusion}

In this study, a special $\mathrm{Al}_{2} \mathrm{O}_{3}$ ceramic with complex shape, high strength, and fine grained and homogeneous microstructure was successfully fabricated by a novel approach integrating DLP-stereolithography and chemical precipitation coating (CP) process. The CP process was used to synthetize $\mathrm{Y}_{2} \mathrm{O}_{3}$-coated $\mathrm{Al}_{2} \mathrm{O}_{3}$ composite powder, which was then used to print complex-shaped $\mathrm{Al}_{2} \mathrm{O}_{3}$ bodies via DLP-stereolithography. It was found that:

(1) The microstructure, phase and surface element present analyses for the CP processed $\mathrm{Al}_{2} \mathrm{O}_{3}$ powder clearly demonstrates that an amorphous $\mathrm{Y}_{2} \mathrm{O}_{3}$ layer can be fully wrapped on the surface of $\mathrm{Al}_{2} \mathrm{O}_{3}$ powder, which will be favorable for improving the dispersive homogeneity of $\mathrm{Y}_{2} \mathrm{O}_{3}$ in $\mathrm{Al}_{2} \mathrm{O}_{3}$.

(2) The phase and microstructure comparisons among the $3 \mathrm{D}$ printed $\mathrm{Al}_{2} \mathrm{O}_{3}$ samples prepared via the pure $\mathrm{Al}_{2} \mathrm{O}_{3}$ powder $(A L), C P$, and mechanical mixing $(M M)$ processed $\mathrm{Y}_{2} \mathrm{O}_{3}-$ 
$\mathrm{Al}_{2} \mathrm{O}_{3}$ powders shows: i) the introduction of $\mathrm{Y}_{2} \mathrm{O}_{3}$ into $\mathrm{Al}_{2} \mathrm{O}_{3}$ can result in the generation of $\mathrm{Y}_{3} \mathrm{Al}_{5} \mathrm{O}_{12}$ phase precipitations, which can reduce the grain size of $\mathrm{Al}_{2} \mathrm{O}_{3}$ due to the precipitation pinning; ii) compared to the conventional MM process, the $\mathrm{CP}$ process can make the microstructure of the $3 \mathrm{D}$ printed $\mathrm{Y}_{2} \mathrm{O}_{3}-\mathrm{Al}_{2} \mathrm{O}_{3}$ system denser, more uniform and refined.

(3) Sample CP has a flexural strength of $455.37 \pm 32.17 \mathrm{MPa}$ and a Weibull modulus of 16.88 , which are $15.10 \%$ and $76.02 \%$ higher than those obtained for Sample MM, due to the grain refinement and microstructure uniformity enhancement. In addition, Sample CP has much higher flexural strength and Weibull modulus compared to Sample AL, indicating the $\mathrm{CP}$ process is conductive to simultaneously improving the flexural strength and reliability of the $3 \mathrm{D}$ printed $\mathrm{Al}_{2} \mathrm{O}_{3}$ ceramic.

(4) The CP process can refine the microstructure of $\mathrm{Y}_{2} \mathrm{O}_{3}-\mathrm{Al}_{2} \mathrm{O}_{3}$ system at no expense of the thermal conductivity. The fine grained Sample CP has a close thermal conductivity $\left(28.95 \pm 0.28 \mathrm{~W} \cdot \mathrm{m}^{-1} \cdot \mathrm{K}^{-1}\right)$ to the coarse grained Sample MM $\left(29.16 \pm 0.55 \mathrm{~W} \cdot \mathrm{m}^{-1} \cdot \mathrm{K}^{-1}\right)$, because the $\mathrm{CP}$ process can facilitate the formation of $\mathrm{Y}_{3} \mathrm{Al}_{5} \mathrm{O}_{12}$ phase as isolated pockets at corners of $\mathrm{Al}_{2} \mathrm{O}_{3}$ grains, which can benefit the decrease of phonon scattering caused by the second phase.

(5) Some fin-type $\mathrm{Al}_{2} \mathrm{O}_{3}$ ceramic heat sinks were successfully fabricated via the $\mathrm{CP}$ process followed by DLP-stereolithography, which may offer a new opportunity for thermal management applications of $\mathrm{Al}_{2} \mathrm{O}_{3}$ ceramic.

\section{Acknowledgement}

This work was supported by the Local Innovative and Research Team Project of 
Guangdong Province (Grant No. 2017BT01C169), the Opening Project of State Key Laboratory of Green Building Materials (Grant No. 2019GBM03), the Guangdong Basic and Applied Basic Research Foundation (Grant No. 2020A1515010004), the Natural Science Foundation of Guangdong Province (Grant No. 2018A030313353), and the Science and Technology Program of Guangzhou (Grant No. 201904010357).

\section{References}

[1] Ge R, Zhang Y, Liu YJ, et al. Effect of $\mathrm{Gd}_{2} \mathrm{O}_{3}$ addition on mechanical, thermal and shielding properties of $\mathrm{Al}_{2} \mathrm{O}_{3}$ ceramics. J Mater Sci: Mater Electron 2017, 28: 5898-5905.

[2] Dong GC, Chen X, Zhang XJ, et al. Thermal fatigue behaviour of $\mathrm{Al}_{2} \mathrm{O}_{3}-\mathrm{DBC}$ substrates under high temperature cyclic loading. Solder Surf Mt Tech 2010, 22: 43-48.

[3] Santos WND, Filho PIP, Taylor R. Effect of addition of niobium oxide on the thermal conductivity of alumina. J Eur Ceram Soc 1998, 18: 807-811.

[4] Wu H, Liu W, Lin L, et al. Preparation of alumina-toughened zirconia via 3D printing and liquid precursor infiltration: manipulation of the microstructure, the mechanical properties and the low temperature aging behavior. J Mater Sci 2019, 54: 7447-7459.

[5] Baklouti S, Bouaziz J, Chartier T, et al. Binder burnout and evolution of the mechanical strength of dry-pressed ceramics containing poly(vinyl alcohol). J Eur Ceram Soc 2001, 21: 1087-1092.

[6] Xie R, Zhang D, Zhang X, et al. Gelcasting of alumina ceramics with improved green strength. Ceram Int 2012, 38: 6923-6926. 
[7] Liu W, Xie Z. Pressureless sintering behavior of injection molded alumina ceramics. Sci Sinter 2014, 46: 3-13.

[8] He R, Liu W, Wu Z, et al. Fabrication of complex-shaped zirconia ceramic parts via a DLP-stereolithography-based 3D printing method. Ceram Int 2018, 44: 3412-3416.

[9] Wu H, Liu W, He R, et al. Fabrication of dense zirconia-toughened alumina ceramics through a stereolithography-based additive manufacturing. Ceram Int 2017, 43: 968-972.

[10] Singh S, Ramakrishna S, Singh R. Material issues in additive manufacturing: A review. J Manuf Process 2017, 25: 185-200.

[11] Song X, Chen Y, Lee TW, et al. Ceramic fabrication using mask-image-projectionbased stereolithography integrated with tape-casting. J Manuf Process 2015, 20: 456-464.

[12] Komissarenko DA, Sokolov PS, Evstigneeva AD, et al. Rheological and curing behavior of acrylate-based suspensions for the DLP 3D printing of complex zirconia parts. Materials 2018, 11: 2350.

[13] Chen Z, Li Z, Li J, et al. 3D printing of ceramics: A review. J Eur Ceram Soc 2019, 39: 661-687.

[14] Felzmann R, Gruber S, Mitteramskogler G, et al. Lithography-based additive manufacturing of cellular ceramic structures. Adv Eng Mater 2012, 14: 1-7.

[15] Griffith ML, Halloran JW. Freeform fabrication of ceramics via stereolithography. $J$ Am Ceram Soc 1996, 79: 2601-2608.

[16] Zhou M, Liu W, Wu H, et al. Preparation of a defect-free alumina cutting tool via additive manufacturing based on stereolithography - optimization of the drying and debinding 
processes. Ceram Int 2016, 42: 11598-11602.

[17] Santoliquido O, Colombo P, Ortona A. Additive manufacturing of ceramic components by digital light processing: A comparison between the "bottom-up" and the "topdown" approaches. J Eur Ceram Soc 2019, 39: 2140-2148.

[18] Shuai X, Zeng Y, Li P, et al. Fabrication of fine and complex lattice structure $\mathrm{Al}_{2} \mathrm{O}_{3}$ ceramic by digital light processing 3D printing technology. J Mater Sci 2020, 55: 6771-6782.

[19] Li H, Liu Y, Liu Y, et al. Influence of vacuum debinding temperature on microstructure and mechanical properties of three-dimensional-printed alumina via stereolithography. 3D Print Addit Manuf 2020, 7: 8-18.

[20] An D, Li H, Xie Z, et al. Additive manufacturing and characterization of complex $\mathrm{Al}_{2} \mathrm{O}_{3}$ parts based on a novel stereolithography method. Int J Appl Ceram Tec 2017, 14: 836844.

[21] An D, Liu W, Xie Z, et al. A strategy for defects healing in 3D printed ceramic compact via cold isostatic pressing: sintering kinetic window and microstructure evolution. $J$ Am Ceram Soc 2019, 102: 2263-2671.

[22] Zhang S, Sha N, Zhao Z. Surface modification of $\alpha-\mathrm{Al}_{2} \mathrm{O}_{3}$ with dicarboxylic acids for the preparation of UV-curable ceramic suspensions. J Eur Ceram Soc 2017, 37: 16071616.

[23] Schwentenwein M, Homa J. Additive manufacturing of dense alumina ceramics. Int J Appl Ceram Tec 2015, 12: 1-7.

[24] Liu W, Wu H, Tian Z, et al. 3D printing of dense structural ceramic microcomponents 
with low cost: Tailoring the sintering kinetics and the microstructure evolution. J Am Ceram Soc 2019, 102: 2257-2262.

[25] Chartier T, Chaput C, Doreau F, et al. Stereolithography of structural complex ceramic parts. J Mater Sci 2002, 37: 3141-3147.

[26] Wu H, Cheng Y, Liu W, et al. Effect of the particle size and the debinding process on the density of alumina ceramics fabricated by 3D printing based on stereolithography. Ceram Int 2016, 42: 17290-17294.

[27] $\mathrm{Li} \mathrm{K}$, Zhao Z. The effect of the surfactants on the formulation of UV-curable SLA alumina suspension. Ceram Int 2017, 43: 4761-4767.

[28] Deng L, Qiao L, Zheng J, et al. Injection molding, debinding and sintering of $\mathrm{ZrO}_{2}$ ceramic modified by silane couping agent. J Eur Ceram Soc 2020, 40: 1566-1573.

[29] Ai YL, Xie XH, He W, et al. Effect of nano- $\mathrm{Al}_{2} \mathrm{O}_{3}$ on the microstructure and properties of $\mathrm{ZrO}_{2}$ dental materials prepared by microwave sintering. Appl Mech Mater 2014, 618: $3-7$.

[30] Miyazakia H, Iwakiri S, Hirao K, et al. Effect of high temperature cycling on both crack formation in ceramics and delamination of copper layers in silicon nitride active metal brazing substrates. Ceram Int 2017, 43: 5080-5088.

[31] Mccune RC, Donlon WT, Ku RC. Yttrium segregation and YAG precipitation at surfaces of yttrium-doped $\alpha-\mathrm{Al}_{2} \mathrm{O}_{3}$. J Am Ceram Soc 1986, 69: 196-199.

[32] Moya EG, Moya F, Lesage B, et al. Yttrium diffusion in $\alpha$-alumina single crystal. $J$ Eur Ceram Soc 1998, 18: 591-594. 
[33] Galusek D, Ghillányová K, Sedlácek J, et al. The influence of additives on microstrucutre of sub-micron alumina ceramics prepared by two-stage sintering. J Eur Ceram Soc 2012, 32: 1965-1970.

[34] Maca K, Pouchlý V, Bodišová K, et al. Densification of fine-grained alumina ceramics doped by magnesia, yttria and zirconia evaluated by two different sintering models. J Eur Ceram Soc 2014, 34: 4363-4372.

[35] Wang R, Zhang D, Zhuang OY, et al. Effect of $\mathrm{Y}_{2} \mathrm{O}_{3}$ content on the properties of alumina-based ceramic cores. Appl Mech Mater 2014, 488-489: 145-149.

[36] Song IG, Kim JS. Enhancement of the mechanical properties of alumina ceramics by a granulation process and $\mathrm{Y}_{2} \mathrm{O}_{3}$ additive. Korean J Met Mater 2015, 53: 262-269.

[37] Wang H, Gao L, Shen Z, et al. Mechanical properties and microstructures of $\mathrm{Al}_{2} \mathrm{O}_{3}$ 5 vol.\% YAG composites. J Eur Ceram Soc 2001, 21: 779-783.

[38] Sang Y, Qin H, Liu H, et al. Partial wet route for YAG powders synthesis leading to transparent ceramic: A core-shell solid-state reaction process. J Eur Ceram Soc 2013, 33: 2617-2623.

[39] Liu Y, Liu R, Liu M. Improved sintering ability of SiC ceramics from $\mathrm{SiC} @ \mathrm{Al}_{2} \mathrm{O}_{3}$ core-shell nanoparticles prepared by a slow precipitation method. Ceram Int 2019, 45: 80328036.

[40] Liu W, Xie ZP, Liu GW, et al. Novel preparation of translucent alumina ceramics induced by doping additives via chemical precipitation method. J Am Ceram Soc 2011, 94: $3211-3215$. 
[41] He X, Ye F, Liu LM, et al. Microstructure and thermal conductivity of spark plasma sintering AlN ceramics. Mater Sci Tech 2011, 27: 513-517.

[42] Lee HM, Bharathi K, Kim DK. Processing and characterization of aluminum nitride ceramics for high thermal conductivity. Adv Eng Mater 2014, 16: 655-669.

[43] Wang W, Xie Z, Liu G, et al. Fabrication of blue-colored zirconia ceramics via heterogeneous nucleation method. Cryst Growth Des 2009, 9: 4373-4377.

[44] Lin L, Wu H, Xu Y, et al. Fabrication of dense aluminum nitride ceramics via digital light processing-based stereolithography. Mater Chem Phys 2020, 249: 122969.

[45] ASTM C1161-13, Standard test method for flexural strength of advanced ceramics at ambient temperature, United States: ASTM International, 2013.

[46] ASTM E1461-13, Standard test method for thermal diffusivity by the flash method, United States: ASTM International, 2013.

[47] Munro RG. Evaluated material properties for a sintered $\alpha$-alumina. J Am Ceram Soc 1997, 80: 1919-1928.

[48] Santos WND, Filho PIP, Taylor R. Effect of addition of niobium oxide on the thermal conductivity of alumina. J Eur Ceram Soc 1998, 18: 807-811.

[49] Kuwano Y, Suda K, Ishizawa N, et al. Crystal growth and properties of (Lu,Y)3 $\mathrm{Al}_{5} \mathrm{O}_{12} . J$ Cryst Growth 2004, 260: 159-165.

[50] Aggarwal RL, Ripin DJ, Ochoa JR, et al. Measurement of thermo-optic properties of $\mathrm{Y}_{3} \mathrm{Al}_{5} \mathrm{O}_{12}, \mathrm{Lu}_{3} \mathrm{Al}_{5} \mathrm{O}_{12}, \mathrm{YAlO}_{3}, \mathrm{LiYF}_{4}, \mathrm{LiLuF}_{4}, \mathrm{BaY}_{2} \mathrm{~F}_{8}, \mathrm{KGd}\left(\mathrm{WO}_{4}\right)_{2}$, and $\mathrm{KY}\left(\mathrm{WO}_{4}\right)_{2}$ laser crystals in the 80-300K temperature range. J Appl Phys 2005, 98: 103514. 
[51] Zhu HB, Li H, Li ZX. Plasma sprayed TiB2-Ni cermet coatings: Effect of feedstock characteristics on the microstructure and tribological performance. Surf Coat Tech 2013, 235: 620-627.

[52] Chen G, Wan J, He N, et al. Strengthening mechanisms based on reinforcement distribution uniformity for particle reinforced aluminum matrix composites. Trans Nonferrous Met Soc China 2018, 28: 2395-2400.

[53] Hayoz J, Bovet M, Pillo T, et al. Oxygen-segregation-controlled epitaxy of $\mathrm{Y}_{2} \mathrm{O}_{3}$ films on $\mathrm{Nb}(110)$. Appl Phys A: Mater Sci Process 2000, 71: 615-618.

[54] Barreca D, Battiston GA, Berto D, et al. $\mathrm{Y}_{2} \mathrm{O}_{3}$ thin films characterized by XPS. Surf Sci Spectra 2001, 8: 234-239.

[55] Kosova N, Devyatkina E, Slobodyuk A, et al. Surface chemistry study of $\mathrm{LiCoO}_{2}$ coated with alumina. Solid State Ion 2008, 179: 1745-1749.

[56] Matsubara I, Paranthaman M, Allison SW, et al. Preparation of Cr-doped $\mathrm{Y}_{3} \mathrm{Al}_{5} \mathrm{O}_{12}$ phosphors by heterogeneous precipitation methods and their luminescent properties. Mater Res Bull 2000, 35: 217-224.

[57] Zhao D, Coyle TW, Chien K. Phase composition and microstructure of yttrium aluminum garnet (YAG) coatings prepared by suspension plasma spraying of $\mathrm{Y}_{2} \mathrm{O}_{3}-\mathrm{Al}_{2} \mathrm{O}_{3}$ powders. Surf Coat Technol 2013, 235: 303-309.

[58] Fang J, Thompson AM, Harmer MP, et al. Effect of yttrium and lanthanum on the final-stage sintering behavior of ultrahigh-purity alumina. J Am Ceram Soc 1997, 80: 20052012. 
[59] Lach R, Wojteczko K, Dudek A, et al. Fracture behaviour of alumina-YAG particulate composites. J Eur Ceram Soc 2014, 34: 3373-3378.

[60] Sommer F, Kern F, El-Maghraby HF, et al. Effect of preparation route on the properties of slip-casted $\mathrm{Al}_{2} \mathrm{O}_{3} / \mathrm{YAG}$ composites. Ceram Int 2012, 38: 4819-4826.

[61] Hansen N. Hall-Petch relation and boundary strengthening. Scr Mater 2004, 51: 801806

[62] Armstrong RW. Grain size dependent alumina fracture mechanics stress intensity. Int J Refract Hard Met 2001, 19: 251-255.

[63] Liu L, Maeda K, Onda T, et al. Microstructure and improved mechanical properties of $\mathrm{Al}_{2} \mathrm{O}_{3} / \mathrm{Ba}-\beta-\mathrm{Al}_{2} \mathrm{O}_{3} / \mathrm{ZrO}_{2}$ composites with YSZ addition. $J$ Eur Ceram Soc 2018, 38: 5113 5121.

[64] ISO 20501:2019(E), Fine ceramics (advanced ceramics, advanced technical ceramics) - Weibull statistics for strength data, Switzerland: International Organization for Standardization, 2019.

[65] Negahdari Z, Willert-Porada M, Scherm F. Thermal properties of homogenous lanthanum hexaaluminate/alumina composite ceramics. J Eur Ceram Soc 2010, 30: 3103-3109.

[66] Watari K, Hwang HJ, Toriyama M, et al. Effective sintering aids for low-temperature sintering of AlN ceramics, J Mater Res 1999, 14: 1409-1417.

[67] Sumirat I, Ando Y, Shimamura S. Theoretical consideration of the effect of porosity on thermal conductivity of porous materials. J Porous Mater 2006, 13: 439-443.

[68] Carson JK, Lovatt SJ, Tanner DJ, et al. An analysis of the influence of material 
structure on the effective thermal conductivity of theoretical porous materials using finite element simulations. Int J Refrig 2003, 26: 873-880.

[69] Smith DS, Fayette S, Grandjean S, et al. Thermal resistance of grain boundaries in alumina ceramics and refractories. J Am Ceram Soc 2003, 86: 105-111.

[70] Hsu HC, Tuan WH. Thermal characteristics of a two-phase composite. Adv Powder Technol 2016, 27: 929-934.

[71] Boey F, Tok AIY, Lam YC, et al. On the effects of secondary phase on thermal conductivity of AlN ceramic substrates using a microstructural modeling approach. Mater Sci Eng A 2002, 335: 281-289.

[72] Hostaša J, Nečina V, Uhlířová T, et al. Effect of rare earth ions doping on the thermal properties of YAG transparent ceramics. J Eur Ceram Soc 2019, 39: 53-58.

[73] Kultayeva S, Ha JH, Malik R, et al. Effects of porosity on electrical and thermal conductivities of porous SiC ceramics. J Eur Ceram Soc 2020, 40: 996-1004.

[74] Onbattuvelli V, Atre S. Review of net shape fabrication of thermally conducting ceramics. Mater Manuf Process 2011, 26: 832-845.

\section{Figure Captions}

Fig. 1 Schematic illustration of the chemical precipitation coating process.

Fig. 2 (a) Representative TEM image of the $\mathrm{CP}$ processed $\mathrm{Y}_{2} \mathrm{O}_{3}-\mathrm{Al}_{2} \mathrm{O}_{3}$ ceramic powder, (b) high magnification TEM image representing the surface of the CP processed powder, (c) 
and (d) are the corresponding fast Fourier transform patterns of the shell and core, (e) and (f) are respective EDS spectra recorded from the shell and core.

Fig. 3 XRD patterns for the $\mathrm{MM}$ and $\mathrm{CP}$ processed $\mathrm{Y}_{2} \mathrm{O}_{3}-\mathrm{Al}_{2} \mathrm{O}_{3}$ composite powders. Right image is the local enlargement of left image marked by green box.

Fig. 4 (a) XPS survey scan of the MM and CP processed $\mathrm{Y}_{2} \mathrm{O}_{3}-\mathrm{Al}_{2} \mathrm{O}_{3}$ powders; (b) and (c) respective XPS core level spectra of $\mathrm{Y}_{3 \mathrm{~d}}$ in the $\mathrm{MM}$ and $\mathrm{CP}$ processed $\mathrm{Y}_{2} \mathrm{O}_{3}-\mathrm{Al}_{2} \mathrm{O}_{3}$ powders.

Fig. 5 XRD patterns for the prepared $\mathrm{Al}_{2} \mathrm{O}_{3}$ ceramic samples.

Fig. 6 Microstructures and grain size statistics of (a) Sample AL, (b) Sample MM and (c) Sample CP.

Fig. 7 SEM micrographs of the fracture surfaces of (a) Sample AL, (b) Sample MM and (c) Sample CP.

Fig. 8 Weibull plots for the flexural strength of Samples AL, MM and CP.

Fig. 9 SEM images and corresponding EDS mappings for $\mathrm{Y}$ on the fracture surfaces of Sample MM (a1, a2) and Sample CP (b1, b2); SEM micrographs of the polished and etched surfaces of Sample MM (a3) and Sample CP (b3). The semi-connected second phases are marked with red circles.

Fig. 10 Optical image of fin-type $\mathrm{Al}_{2} \mathrm{O}_{3}$ ceramic heat sinks fabricated by a novel approach integrating DLP-stereolithography and CP process. 
Tables

Table 1 Chemical compositions (at $\%$ ) of the $\mathrm{MM}$ and $\mathrm{CP}$ processed $\mathrm{Y}_{2} \mathrm{O}_{3}-\mathrm{Al}_{2} \mathrm{O}_{3}$

powders

\begin{tabular}{ccccr}
\hline Sample & $\mathrm{C}_{1 \mathrm{~s}}$ & $\mathrm{O}_{1 \mathrm{~s}}$ & $\mathrm{Al}_{2 \mathrm{p}}$ & $\mathrm{Y}_{3 \mathrm{~d}}$ \\
\hline $\mathrm{MM}$ processed $\mathrm{Y}_{2} \mathrm{O}_{3}-\mathrm{Al}_{2} \mathrm{O}_{3}$ powder & 24.88 & 44.76 & 30.29 & 0.07 \\
$\mathrm{CP}$ processed $\mathrm{Y}_{2} \mathrm{O}_{3}-\mathrm{Al}_{2} \mathrm{O}_{3}$ powder & 36.62 & 39.52 & 19.75 & 4.11 \\
\hline
\end{tabular}

Table 2 Phase content in the prepared $\mathrm{Al}_{2} \mathrm{O}_{3}$ ceramics estimated by the semi-

quantitative method

\begin{tabular}{ccc|cc}
\hline \multirow{2}{*}{ Sample } & \multicolumn{2}{c|}{$\begin{array}{c}\text { Semi-quantitative phase } \\
\text { content in ceramics } / \mathrm{wt} \%\end{array}$} & \multicolumn{2}{c}{$\begin{array}{c}\text { Semi-quantitative phase content } \\
\text { in ceramics } / \text { vol\% }\end{array}$} \\
\cline { 2 - 5 } & $\mathrm{Al}_{2} \mathrm{O}_{3}$ & $\mathrm{Y}_{3} \mathrm{Al}_{5} \mathrm{O}_{12}$ & $\mathrm{Al}_{2} \mathrm{O}_{3}$ & $\mathrm{Y}_{3} \mathrm{Al}_{5} \mathrm{O}_{12}$ \\
\hline $\mathrm{AL}$ & 100.00 & 0 & 100.00 & 0 \\
$\mathrm{MM}$ & 91.84 & 8.16 & 92.79 & 7.21 \\
$\mathrm{CP}$ & 91.26 & 8.74 & 92.27 & 7.73 \\
\hline
\end{tabular}

Table 3 Mechanical and thermal properties of the $3 \mathrm{D}$ printed $\mathrm{Al}_{2} \mathrm{O}_{3}$ ceramics

\begin{tabular}{cccc}
\hline Sample & $\begin{array}{c}\text { Relative density } \\
/ \%\end{array}$ & $\begin{array}{c}\text { Flexural strength } \\
\text { /MPa }\end{array}$ & $\begin{array}{c}\text { Thermal conductivity } \\
/ \mathrm{W} \cdot \mathrm{m}^{-1} \cdot \mathrm{K}^{-1}\end{array}$ \\
\hline AL & $98.19 \pm 0.12$ & $362.98 \pm 28.61$ & $33.40 \pm 1.51$ \\
$\mathrm{MM}$ & $97.31 \pm 0.23$ & $396.50 \pm 46.84$ & $29.16 \pm 0.55$ \\
$\mathrm{CP}$ & $97.53 \pm 0.15$ & $455.37 \pm 32.17$ & $28.95 \pm 0.28$ \\
\hline
\end{tabular}


Table 4 A comparison between the calculated and measured thermal conductivities of

$\mathrm{Y}_{2} \mathrm{O}_{3}-\mathrm{Al}_{2} \mathrm{O}_{3}$ system

\begin{tabular}{cccccccc}
\hline $\begin{array}{c}\text { Calculation } \\
\text { model }\end{array}$ & Sample & $\lambda_{\mathrm{s}}$ & $\lambda_{\mathrm{p}}$ & $\lambda_{\mathrm{c} 0}$ & $\varphi$ & $\lambda_{\text {c-calculated }}$ & $\lambda_{\text {c-measured }}$ \\
\hline \multirow{2}{*}{$\mathrm{ME}$} & $\mathrm{MM}$ & 34.32 & 10.70 & 32.16 & $2.69 \%$ & 30.88 & 29.16 \\
& $\mathrm{CP}$ & 34.32 & 10.70 & 32.00 & $2.47 \%$ & 30.83 & 28.95 \\
\hline \multirow{2}{*}{ EMT } & $\mathrm{MM}$ & 34.32 & 10.70 & 32.13 & $2.69 \%$ & 30.85 & 29.16 \\
& $\mathrm{CP}$ & 34.32 & 10.70 & 31.97 & $2.47 \%$ & 30.80 & 28.95 \\
\hline
\end{tabular}




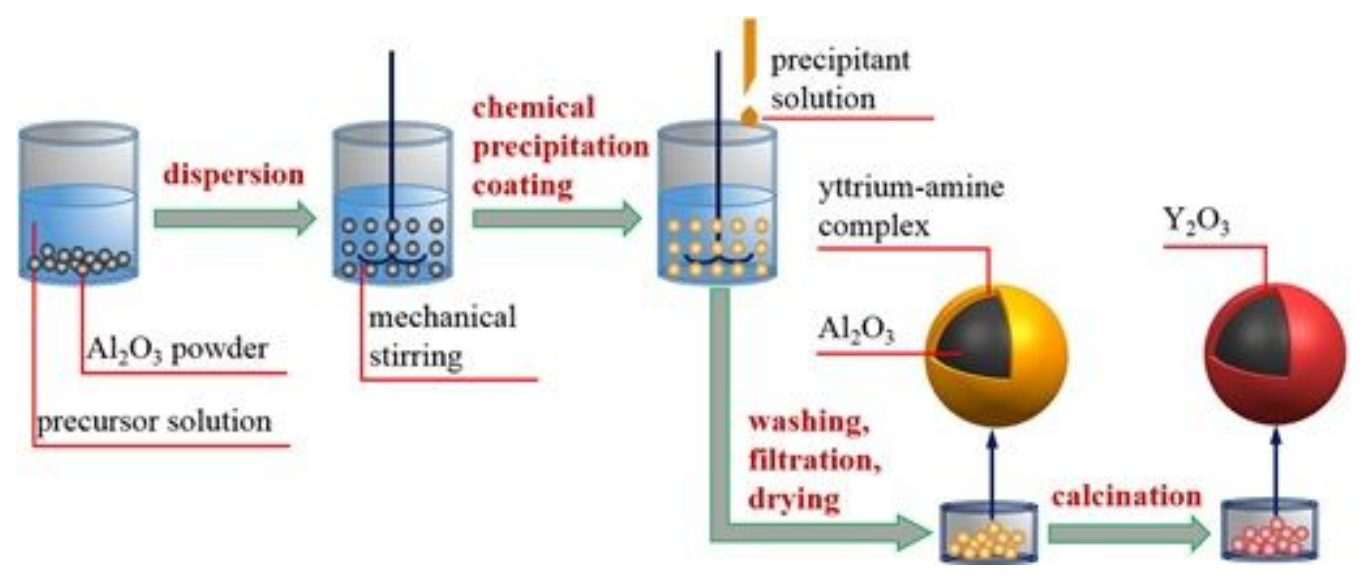

Figure 1

Schematic illustration of the chemical precipitation coating process.
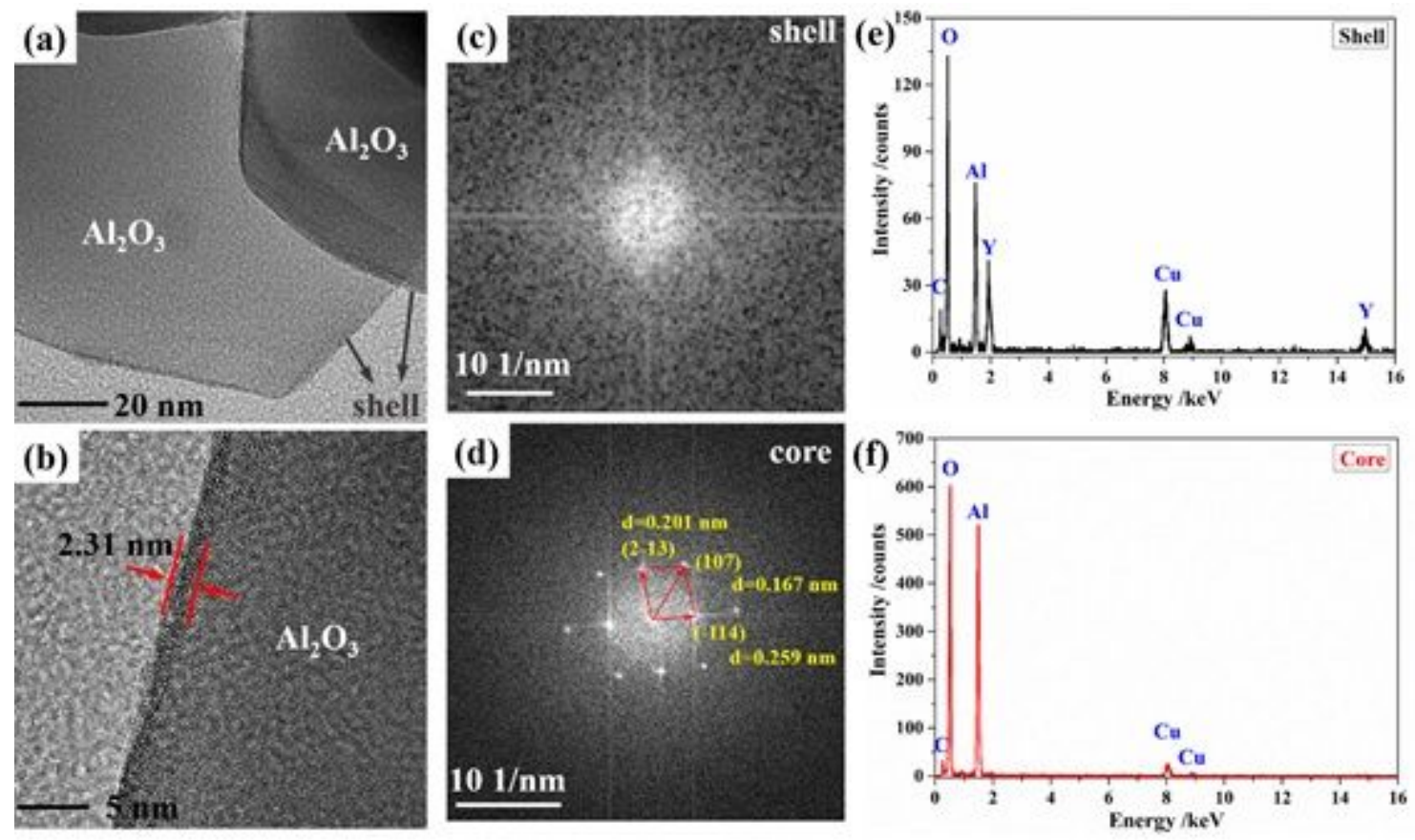

Figure 2

(a) Representative TEM image of the CP processed Y2O3-Al2O3 ceramic powder, (b) high magnification TEM image representing the surface of the CP processed powder, (c) and (d) are the corresponding fast Fourier transform patterns of the shell and core, (e) and (f) are respective EDS spectra recorded from the shell and core. 

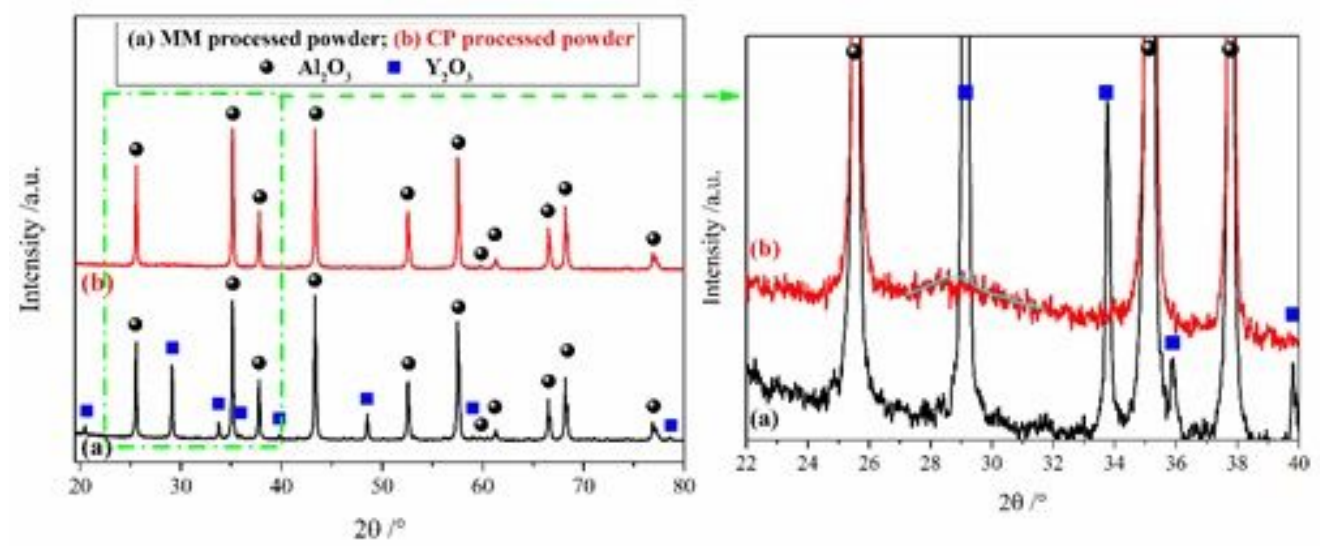

Figure 3

XRD patterns for the MM and CP processed Y203-Al2O3 composite powders. Right image is the local enlargement of left image marked by green box.
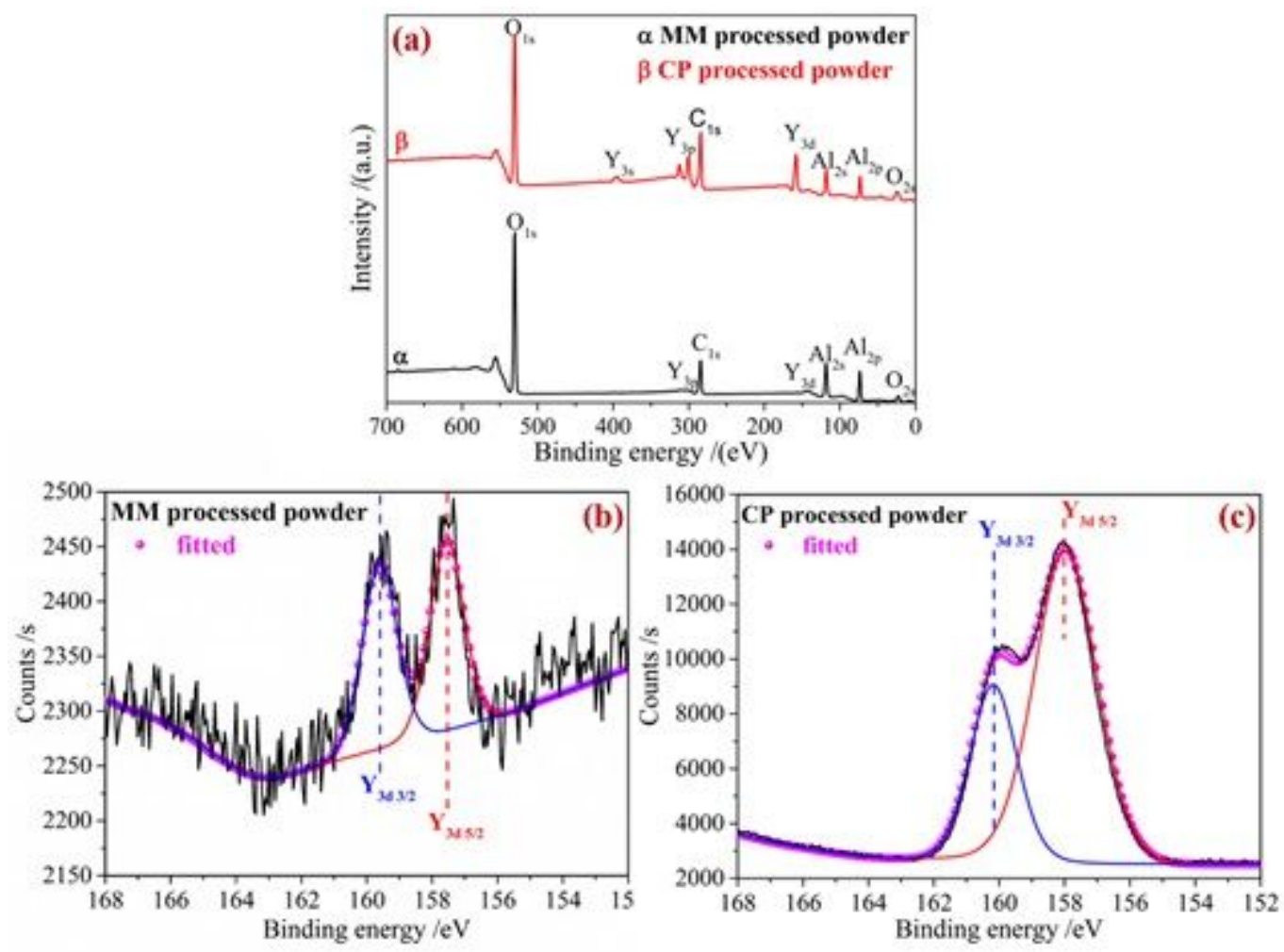

\section{Figure 4}

(a) XPS survey scan of the MM and CP processed Y203-Al2O3 powders; (b) and (c) respective XPS core level spectra of Y3d in the MM and CP processed Y203-Al2O3 powders. 


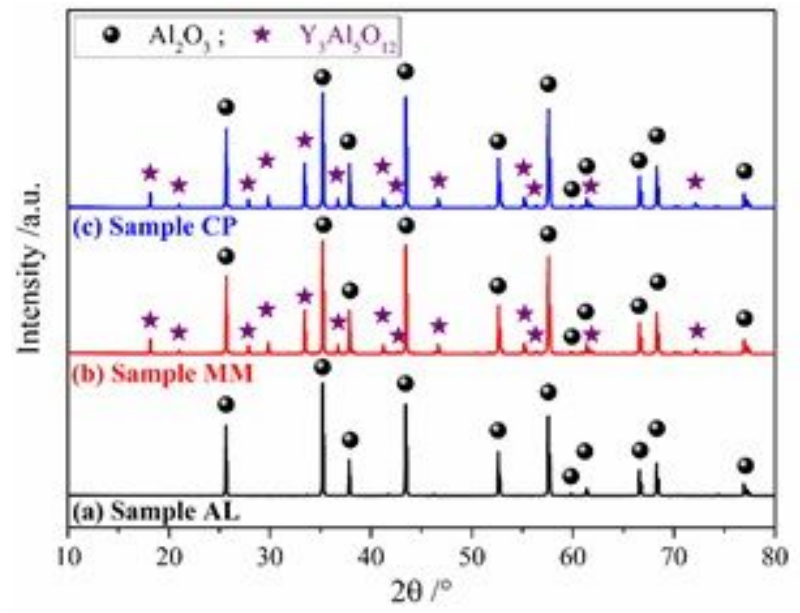

Figure 5

XRD patterns for the prepared Al203 ceramic samples.
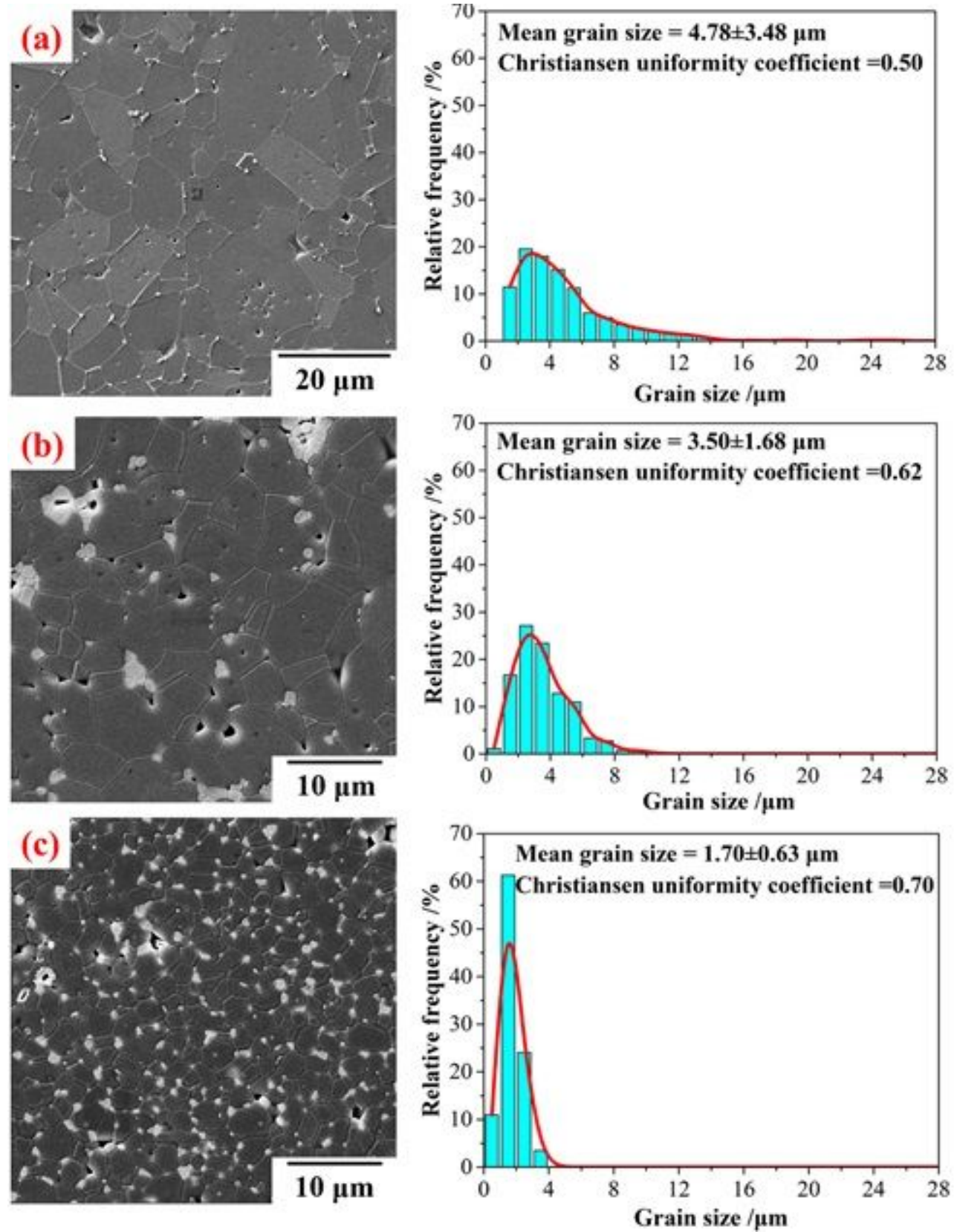
Figure 6

Microstructures and grain size statistics of (a) Sample AL, (b) Sample MM and (c) Sample CP.
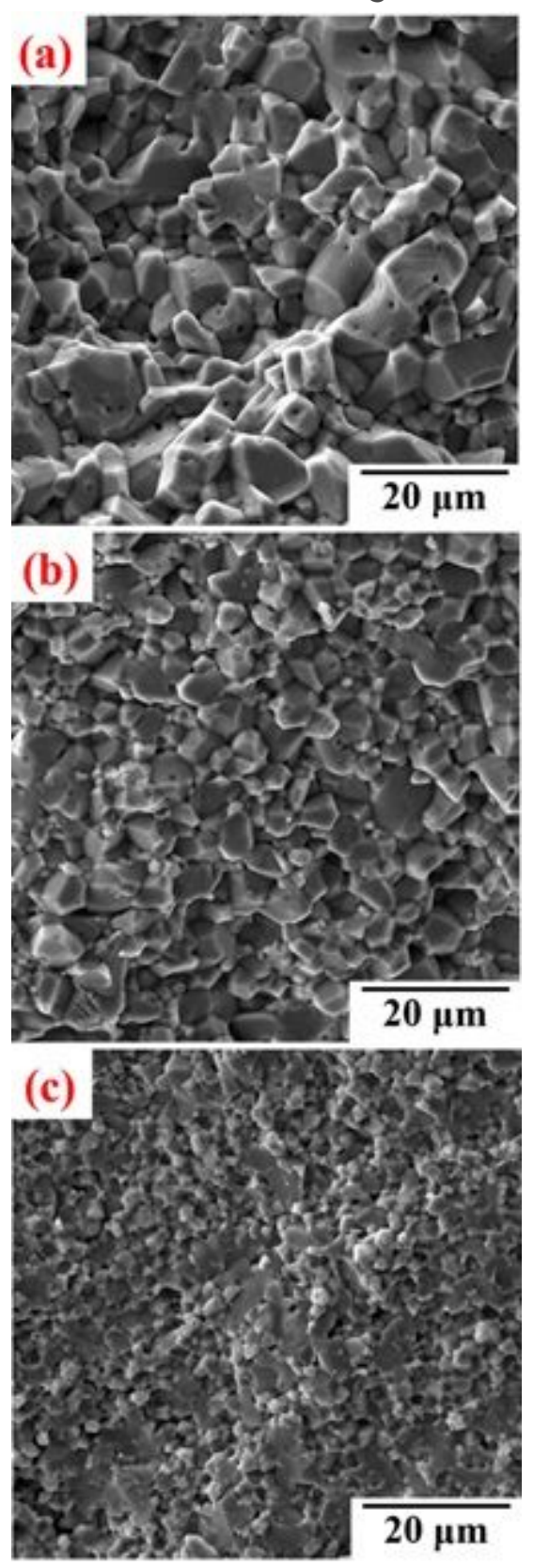

Figure 7

SEM micrographs of the fracture surfaces of (a) Sample AL, (b) Sample MM and (c) Sample CP. 


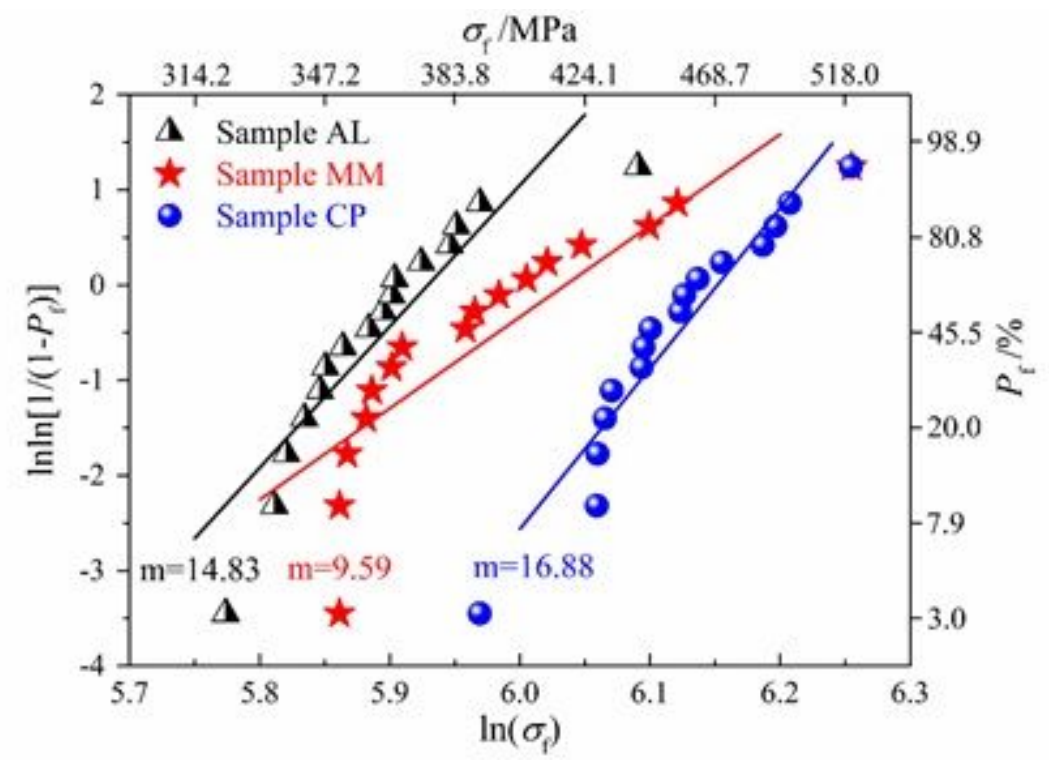

Figure 8

Weibull plots for the flexural strength of Samples AL, MM and CP.
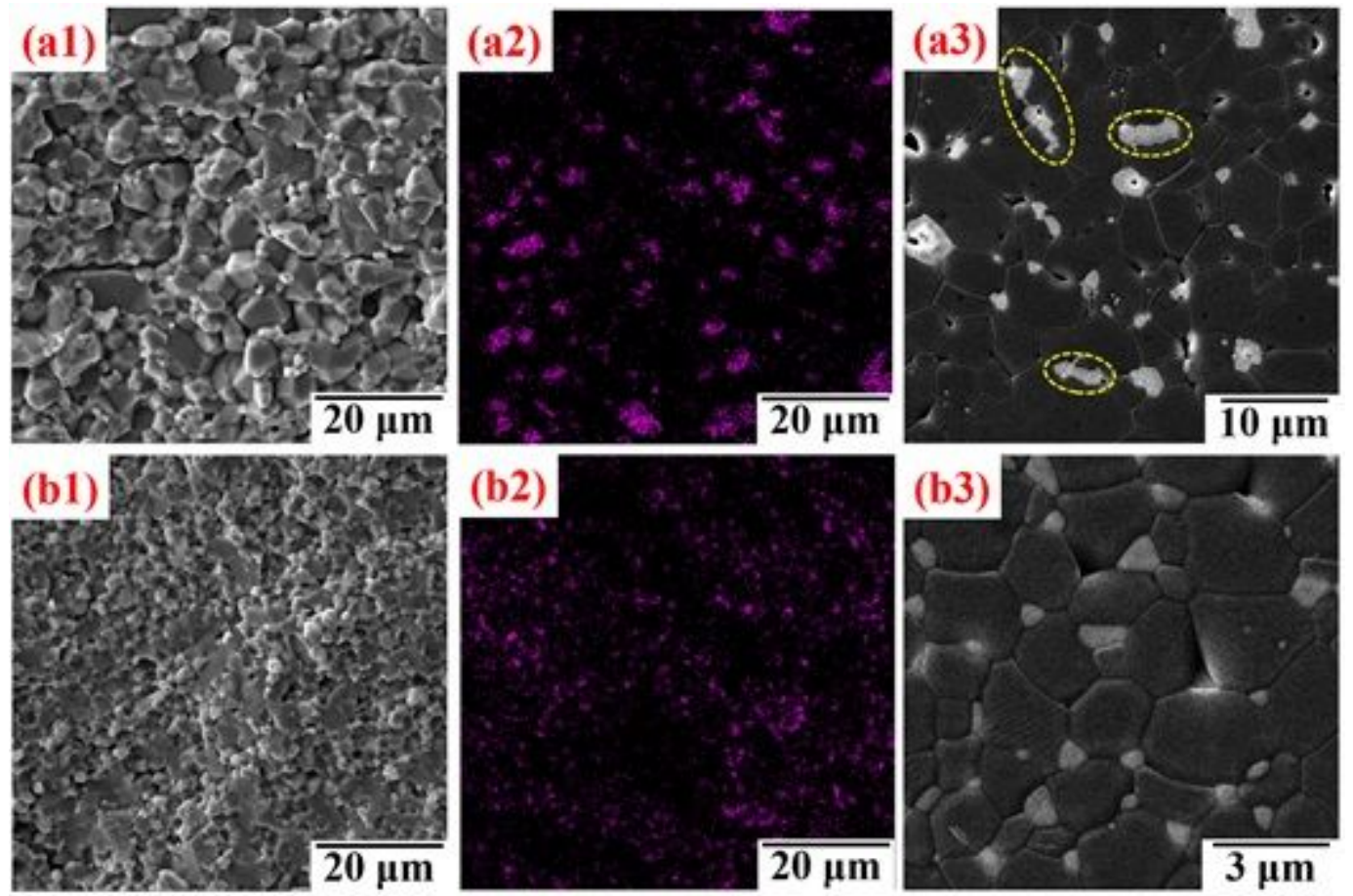

Figure 9

SEM images and corresponding EDS mappings for $Y$ on the fracture surfaces of Sample MM (a1, a2) and Sample CP (b1, b2); SEM micrographs of the polished and etched surfaces of Sample MM (a3) and Sample CP (b3). The semi-connected second phases are marked with red circles. 


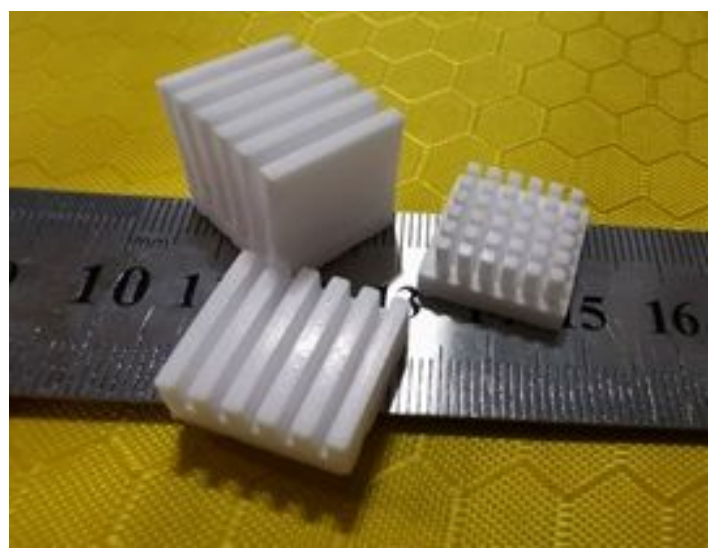

Figure 10

Optical image of fin-type Al2O3 ceramic heat sinks fabricated by a novel approach integrating DLPstereolithography and CP process. 